\title{
Bone Health in Children and Youth with Cystic Fibrosis: A Systematic Review and Meta-Analysis of Matched Cohort Studies
}

Esther Ubago-Guisado, $\mathrm{PhD}^{1}$, Ivan Cavero-Redondo, $\mathrm{PhD}^{1,2,3}$, Celia Alvarez-Bueno, $\mathrm{PhD}^{1,2,3}$, Dimitris Vlachopoulos, $\mathrm{PhD}^{4}$, Vicente Mart_1nez-Vizca_1no, PhD, $\mathrm{MD}^{1,5}$, and Luis Gracia-Marco, $\mathrm{PhD}^{6,7}$

Objective: To assess the evidence regarding the differences in areal bone mineral density (aBMD) between children and adolescents with cystic fibrosis (CF) compared with their healthy peers, based on data from longitudinal studies. Study design: We searched MEDLINE, SPORTDiscus, the Cochrane Library, PEDro (Physiotherapy Evidence Database), and Embase databases. Observational studies addressing the change of aBMD in children with CF and healthy children and adolescents were eligible. The DerSimonian and Laird method was used to compute pooled estimates of effect sizes (ES) and 95\% CIs for the change of whole body (WB), lumbar spine (LS), and femoral neck (FN) aBMD. Results: Six studies with participants with CF and 26 studies with healthy participants were included in the systematic review and meta-analysis. For the analysis in children with $\mathrm{CF}$, the pooled ES for the change of WB aBMD was 0.29 (95\% CI -0.15 to 0.74$)$, for the change of LS aBMD was 0.13 (95\% CI -0.16 to 0.41 ), and for the change of FN aBMD was 0.09 (95\% CI -0.39 to 0.57 ). For the analysis in healthy children, the pooled ES for the change of WB aBMD was 0.37 (95\% CI 0.26-0.49), for the change of LS aBMD was $0.13(95 \% \mathrm{CI}-0.16$ to 0.41$)$, and for the change of $\mathrm{FN}$ aBMD was $0.52(95 \%$ CI 0.19-0.85). Conclusions: aBMD development might not differ between children and adolescents with $\mathrm{CF}$ receiving medical care compared with their healthy peers. Further longitudinal studies in a CF population during growth and development are required to confirm our findings. 


\section{Introduction}

Cystic fibrosis $(\mathrm{CF})$ is an inherited disease affecting the correct functioning of numerous vital organs, such as the lungs and the gastrointestinal tract (1). It is caused by mutations in the Cystic Fibrosis Transmembrane Conductance Regulator (CFTR) gene and it is the most prevalent (autosomal recessive) disorder in the Caucasian-race population. The median age at death, 29.1 years, has continuously increased over the last two decades, and nowadays more than half of the individuals with CF are 18 years or older (2), suggesting an increase in the likelihood of having long-term CF sequels. These include low areal bone mineral density (aBMD), osteoporosis-related fractures and abnormal excessive convex curvature of the spine (e.g. kyphosis) (3-5), which in turn may cause pain when breathing and impair physical activity levels, which can contribute to bone accrual (6). CF is also related to exocrine pancreatic insufficiency, characterised by a deficiency in the number of exocrine pancreatic enzymes and causing an inability to digest food and absorb nutrients, which affects proper development in children and adolescents with CF $(1,7)$. In this regard, a poor nutritional status has been associated with a reduction in lung function, impaired pulmonary muscle function, and tolerance levels towards exercise (8).

Multiple factors seem to explain the link between low aBMD and CF, including poor nutritional status, nutrient malabsorption and clinical status (9-12) but also a more direct pathway through the CFTR gene mutation, which may lower aBMD (11). The association between aBMD and CF may vary depending on whether it is looked at in growing or adult population. Findings from a systematic review and meta-analysis showed that $38 \%$ and $23.5 \%$ of the adults with CF had osteopenia and osteoporosis, respectively (13). It is 
known that bone acquisition occurs throughout childhood and adolescence, with 80-90 \% acquired by late adolescence, depending of the sites of the skeleton $(14,15)$. Therefore, the origins of bone disease in CF are likely to occur during childhood or adolescence.

The scientific evidence regarding bone mineralization in $\mathrm{CF}$ is controversial $(4,16-20)$. Some evidence points out the prevalence of low aBMD in children and adolescents (2123), and suggest lung function and nutritional status as important determinants of low aBMD in CF (16, 23-25). The study of Reix, Bellon (26) showed that bone alterations may be already present in children younger than 6 years of age, and highlighted that monitoring bone status in this population is needed. In contrast, other studies highlight a minimal difference in bone mass in $\mathrm{CF}$ (relative to normal) but that this difference is more important at later life stages, such as adulthood (27-29). In this regard, the CF Foundation consensus statement on bone health and disease recommends monitoring $\mathrm{CF}$ adults with Dual energy X-ray Absorptiometry (DXA) and subsequent follow-up based on the findings (2).

DXA is considered the gold standard method for assessing aBMD and has been used worldwide not only in adults but also in children and adolescents (30). In a clinical setting, the most common sites measured with DXA are the lumbar spine, hip (total hip or proximal femur), and total body $(31,32)$. Considering the increase in life expectancy in people with $\mathrm{CF}$ and associated sequels, such as the increased risk of osteoporosis, examining whether low bone mass is already apparent in children and adolescents with CF must be viewed as a high priority. To the best of our knowledge, no meta-analysis has analysed whether aBMD differs between CF and healthy children and adolescents. 
Therefore, this systematic review and meta-analysis aims to examine the differences in aBMD between children and adolescents with CF compared to their healthy peers based on data from longitudinal studies.

\section{Methods}

This study was reported according to the Meta-analysis of Observational Studies in Epidemiology statements (MOOSE) (33) and followed the recommendations of the Cochrane Collaboration Handbook (34). This systematic review and meta-analysis was registered through the International Prospective Register of Systematic Reviews (Registration number: CRD42018099671).

\section{Search strategy}

We systematically searched MEDLINE (via PubMed), SPORTDiscus, the Cochrane Library, PEDro (Physiotherapy Evidence Database) and Scopus (via databases from their inception until October, 2018). Observational studies addressing the change of aBMD in both, cystic fibrosis and healthy, across the childhood and adolescence period were eligible. The search strategy included the following terms for cystic fibrosis populations: (bone) AND (children OR adolescents OR young OR boys OR girls) AND ("cystic fibrosis"); and for healthy populations: (bone) AND (children OR adolescents OR young OR boys OR girls) AND (healthy). The literature search was complemented by reviewing citations of the articles considered eligible for the systematic review and authors were contacted to obtain missing information when necessary. 
The criteria for including studies were as follows: i) participants: cystic fibrosis population samples or healthy population samples; ii) study design: longitudinal studies, with prospective data collection; iii) exposure: bone development during the follow-up; and iv) outcome: aBMD. The criteria for excluding studies were as follows: i) reports not written in English or Spanish; ii) studies including individuals aged below 18 years old; and iii) non-eligible publication types, such as review articles, editorials, comments, guidelines or case-reports.

When more than one study provided data from the same sample, we only considered the one presenting the most detailed results or providing data for the largest sample size. However, data regarding sample characteristics could be extracted from multiple reports to obtain the most complete information

The literature search was independently conducted by two reviewers (EUG and LGM), and disagreements were solved by consensus or involving a third researcher (ICR).

\section{Data extraction and quality assessment}

The following data were extracted from the original reports (1) first author and year of publication, (2) country of the study where data were collected, (3) length of follow-up, (4) sample characteristics (age, sample size, BMI, stature, weight and type of population) and, (5) bone measurement characteristics (aBMD measurement method used, values for each aBMD [WB, LS and FN] at baseline and at end of follow-up).

Quality Assessment tool for Observational Cohort and Cross-sectional Studies from the National Heart, Lung and Blood Institute (35) was used to evaluate risk of bias for cohort and cross-sectional studies. Assessed methodological criteria included: research question, 
population definition, participation rate, recruitment, sample size, analysis, timeframe, exposure levels, measures and assessment, outcome measures and blinding, loss at follow up and confounding variables. Each study was rated either as good (i.e., most criteria met, and with a low risk of bias), fair (i.e., some criteria met, with a moderate risk of bias), or poor (i.e., few criteria met, and with a high risk of bias).

Data extraction and quality assessment were independently performed by two researchers (EUG and LGM), and inconsistencies were solved by consensus or involving a third researcher (ICR).

\section{Statistical analysis and data synthesis}

The inverse-variance fixed effects method (36), were used to compute pooled estimates of effect size (ES) and respective $95 \% \mathrm{CI}$. When the studies presented aBMD mean values for baseline and end-point or aBMD mean value change, effect size (ES) were calculated. ES values around 0.2 were considered to be a weak effect, values around 0.5 were a moderate effect, values around 0.8 were a strong effect, and values larger than 1.0 were a very strong effect. In order to compare the differences in aBMD changes between cystic fibrosis and healthy population the meta-analysis was done separately. The heterogeneity of results across studies was assessed using the $\mathrm{I}^{2}$ statistic (37). $\mathrm{I}^{2}$ values are considered as: might not be important ( $0 \%$ to $40 \%$ ), may represent moderate heterogeneity (30\% to $60 \%$ ), substantial heterogeneity (50\% to $90 \%$ ) or considerable heterogeneity ( $75 \%$ to $100 \%)$; the corresponding p-values were also taken into account (34).

Sensitivity analyses (systematic re-analysis while removing studies one at a time), and subgroup analyses were conducted in order to assess the robustness of the summary 
estimates. Results of the sensitivity analyses were considered meaningful when the resulting estimates were modified beyond the confidence intervals of the original summary estimate. In addition, sensitivity analyses provided insight as to whether any particular study or subgroup accounted for a large proportion of heterogeneity among the correlation pooled estimations, based on the change in $\mathrm{I}^{2}$ values (and associated categories previously reported).

Random-effects meta-regression analyses were performed to determine whether age and length of follow-up to examine their interaction effect on the aBMD change comparing healthy and cystic fibrosis populations. Finally, to assess publication bias, Egger's regression asymmetry test was used (38). A level of $<0.10$ was used to determine if publication bias might be present. Statistical analyses were performed using StataSE software, version 14 (StataCorp).

\section{Results}

\section{Systematic Review}

We identified 6 longitudinal studies (Table 1) (21, 39-43) about the development of aBMD in children and adolescents with cystic fibrosis. In parallel, we identified 29 studies (Table 2) (44-72) with longitudinal data of aBMD in healthy children and adolescents. The compilation of these studies allow us to compare the status of bone health in cystic fibrosis young with a healthy peers (control studies) over the time.

Regarding to the cystic fibrosis studies, these were carried out in 4 different countries: three from USA, one from Italy, one from New Zealand and one from Hungary. Reports were published between 1998 and 2017, and they included longitudinal studies using the 
following designs: five were follow-up non-randomised studies and one was a randomised trial. Length of studies ranged from 9 months to 5 years.

All the participants suffered cystic fibrosis and one of the study the participants underwent liver transplantation. Included participants were aged between 4 and 18 years, with sample sizes ranging from 9 to 40 subjects. Concerning assessment methods carried out in the studies, all of them used a dual-energy x-ray absorptiometry scanner to measure bone outcomes: two studies used the model Hologic 1000W, one study used the model Hologic QDR 2000, two studies used the model Hologic QDR-4500, and one study used the model Lunar Prodigy.

Regarding to the control studies, these were realised in 12 different countries: one from Brazil, two from Spain, three from Switzerland, five from Australia, four from Canada, seven from USA, one from United Kingdom, one from Estonia, one from France, two from Sweden, one from Belgium and one from Denmark. Data were published between 1991 and 2017 and they included longitudinal studies using the following designs: twelve were follow-up non-randomised studies and seventeen were randomised-controlled trial. Length of studies ranged from 3 months to 14 years.

All the participants were healthy children and adolescents. The range age of the participants was 4 to 18 years, with sample sizes between 9 to 124 . Concerning assessment methods carried out in the studies, all of them used a dual-energy x-ray absorptiometry scanner to measure bone outcomes: eight studies used the model Lunar Prodigy, one study used the model Hologic QDR 1500, three studies used the model Hologic QDR 2000, five studies used the model Hologic QDR 1000W, ten studies used 
the model Hologic QDR 4500, one study used the model Hologic WB Delphi, and one study used the model Norland Medical XR800.

\section{Study Quality}

The risk of bias was evaluated by a quality assessment tool for observational cohort and cross-sectional studies for The National Institutes of Health (73). The cystic fibrosis studies showed a $33.3 \%$ of high risk of bias and $66.7 \%$ of moderate risk of bias. The control studies showed a $51.7 \%$ of high risk of bias, a $44.8 \%$ of moderate risk of bias, and a $3.4 \%$ of low risk of bias.

When studies were analysed by individual domains, $100 \%$ of the cystic fibrosis studies defined a clearly research question, took into account the exposure(s) of interest measured prior to the outcome(s) being measured, the timeframe was sufficient, the exposure measures (independent and dependent variables) were clearly defined, valid, reliable, and implemented consistently, and presented a lower percentage of $20 \%$ of withdrawals/dropouts. However, no study or just one had presented a sample size justification (power description, or variance and effect estimates) and had shortcomings in the blinding domain. On the other hand, approximately $100 \%$ of the control studies defined a clearly research question, the timeframe was sufficient, and the exposure measures (independent and dependent variables) were clearly defined, valid, reliable, and implemented consistently. However, less than $25 \%$ had presented a sample size justification (power description, or variance and effect estimates) and have shortcomings in the blinding domain.

(Electronic Supplementary Material Tables S2 and S3). 
To more clearly display the pooled ES estimates of WB, LS, and FN aBMD, we have provided forest plots including the pooled ES estimates, their 95\% CI and the $\mathrm{I}^{2}$ heterogeneity statistic for healthy and cystic fibrosis children (Figures 2-4).

\section{WB aBMD}

Finally, for the analysis in cystic fibrosis children, the pooled ES for the change of WB aBMD was 0.29 (95\% CI -0.15-0.74), with no heterogeneity $\left(\mathrm{I}^{2}=0.0 \% ; \mathrm{p}=0.829\right)$. Furthermore, for the analysis in healthy children, the pooled ES for this change was 0.25 (95\% CI 0.13-0.37), with not important heterogeneity $\left(\mathrm{I}^{2}=35.8 \% ; \mathrm{p}=0.071\right)$ (Figure 2).

\section{LS aBMD}

Additionally, regarding the change of LS aBMD, the pooled ES in cystic fibrosis children was $0.13(95 \%$ CI $-0.16-0.41)$, with no heterogeneity $\left(\mathrm{I}^{2}=0.0 \% ; \mathrm{p}=1.000\right)$. Besides in healthy children the pooled ES was 0.29 (95\% CI 0.18-0.40), with not important heterogeneity $\left(\mathrm{I}^{2}=21.0 \% ; \mathrm{p}=0.209\right)$ (Figure 3$)$.

\section{FN aBMD}

For the analysis in cystic fibrosis children, the pooled ES for the change of FN aBMD was 0.09 (95\% CI -0.39-0.57), with no heterogeneity $\left(\mathrm{I}^{2}=0.0 \% ; \mathrm{p}=0.999\right)$. Furthermore, for the analysis in healthy children, the pooled ES for this change was 0.20 (95\% CI 0.11$0.30)$, also with no heterogeneity $\left(I^{2}=0.0 \% ; p=0.558\right)$ (Figure 4$)$. 
The pooled ES estimate was not significantly modified in magnitude or direction when individual study data were removed from the analysis one at a time.

The random-effects meta-regression model showed that length of follow up, age, BMI, height and weight were not related to FN, LS or WB aBMD change across studies either for cystic fibrosis children or for healthy children (Figures $\mathrm{XXX}-\mathrm{XXX}$ in the Supplementary file).

Finally, evidence of publication bias was found by funnel plot asymmetry and Egger's test for the change of LS aBMD in cystic fibrosis children $(p=0.027)$ and for the change of WB aBMD in healthy children $(\mathrm{p}=0.073)$ (Figures $\mathrm{XXX}-\mathrm{XXX}$ in the Supplementary file).

\section{Discussion}

In the present systematic review and meta-analysis, children and adolescents affected by CF did not present lower aBMD compared with their peers without CF. To the best of our knowledge, this is the first meta-analysis analysing the status of aBMD in CF children and adolescents.

Among other factors, a poor nutritional status, nutrient malabsorption and clinical status have been suggested in previous investigations as determinants that may explain the association between low aBMD and $\mathrm{CF}$ (9-12). However, there is controversial in the scientific literature on whether CF patients present poorer bone mineralization $(4,16-20)$. Our data show that longitudinal changes in WB, LS and FN aBMD in children and adolescents with CF are not different from those found in their healthy peers. These 
results are in accordance with the cross-sectional study by Buntain, Greer (10) in which it was found that well-nourished prepubertal children with $\mathrm{CF}$ had no significant differences in WB, LS and FN aBMD than a healthy control group. Young adults with CF have shown a low bone turnover with reduced bone formation but there is no evidence for increased bone resorption $(74,75)$. Nevertheless, it seems that the prevalence of CFrelated bone disease increases with age $(19,76)$. For example, $<5 \%$ of children with $\mathrm{CF}$ presented bone disease, increasing to $20 \%$ in adolescents and 55 to $65 \%$ in adults older than 45 years (29). Therefore, deficits in aBMD seem to be more evident in adulthood than childhood (10).

In contrast to our findings, previous investigations have shown bone disease in CF youth patients $(16,21-23,26)$. Schulze, Cutchins (41) found that low bone mass was usual among their cohort of adolescent girls with $\mathrm{CF}$, and approximately a $40 \%$ of the girls presented deficits in expected bone mineral content at the lumbar spine, and above $20 \%$ in expected bone mineral content at the WB. In this line, a longitudinal study indicated failure to gain bone at the expected rate in youths (21).

These findings can be extrapolated to the adult population, since it has been demonstrated through anterior research that adults with CF present bone disease $(16,21,23,24)$. In a systematic review and meta-analysis in young adults with $\mathrm{CF}$, the prevalence of osteoporosis was $23.5 \%$, the prevalence of osteopenia was $38.0 \%$, and the prevalence of vertebral and non-vertebral fractures were $14.0 \%$ and $19.7 \%$, respectively (13). In this sense, a longitudinal study showed inadequate values of aBMD in adults (21). These discrepancies and the fact that our meta-analyses did not show differences in aBMD between groups may in part reflect our sample characteristics since participants 
with $\mathrm{CF}$ remained on their standard meds as part of their usual treatment regimen, which included daily multivitamin and mineral supplements as ADEK vitamins, calcium supplementation, and use of pancreatic enzyme supplements, mainly (40-43). In addition, our sample of healthy participants were mostly physically inactive $(44,45,49,51,55$, $57-59,61,64,65,67,72)$ and/or did not meet the minimum calcium and/or vitamin D intake $(46,47,52-54,59,66,68)$. It is known that nutritional status is a major determinant of aBMD (42), importantly vitamin D and K deficiencies, and a negative calcium balance (27). In other words, $\mathrm{CF}$ children who receive the nutritional supplementation as part of their medical treatment do not have their aBMD negatively affected. Similarly, young people with CF has affected bone accrual in those with the poorest nutritional status (42). So, aBMD is usually normal in children with CF with no nutritional deficit (20), which is the case in 4 out of 6 studies (40-43), omitting that information in the other 2 studies (21, 39). Further, it has been demonstrated that calcium absorption is normal in children with $\mathrm{CF}$ (40) and that those who have never received steroid treatment could also present bone deficit (43). So, steroid treatment is not determinant in the development of bone deficit (43). In 4 out of 6 studies $(21,39,41,42)$, some of the patients received steroid treatment while in the other two studies they did not receive $(40,43)$

We must also bear in mind that they are children and, therefore, they are growing. The greatest growth and skeletal maturation occurs at the end of puberty when $\sim 51 \%$ of the peak bone mass is attained (77). In this regard, it has been demonstrated that total body bone mineral content increases across pubertal groups, as a consequence of pubertal growth (41). Therefore, it is important to optimize bone health in children, adolescents and adults with $\mathrm{CF}$ through strategies that include a nutritional plan, vitamin $\mathrm{K}$, vitamin D and calcium supplementation if necessary, and as well as weight bearing exercise (27). 
Exercise during childhood, especially high impact sports (such as football, handball or basketball) have been related to improvements in $\operatorname{aBMD}(78,79)$, and strength at loaded sites (80). Additionally, it is recommended to monitor patients with CF through DXA scanners to have a follow-up of their bone health according to the European Cystic Fibrosis Society (81).

Some limitations need to be acknowledged. First, the limited number of published studies investigating bone health in children and/or adolescence with $\mathrm{CF}$ must be taken into account. For this reason, confidence intervals are large compared to the studies in healthy children and adolescents. Second, data extraction were non-blinded, which is a potential source of bias. Third, $66.7 \%$ of the CF studies and a $44.8 \%$ of the healthy studies presented moderate risk of bias. Fourth, the use of covariates in the studies was heterogeneous, although we have always tried to analyse raw data. Finally, the majority of the studies did not present a sample size justification, and had shortcomings in the blinding domain.

In conclusion, our meta-analysis showed that aBMD values do not differ between wellnourished children and adolescents with $\mathrm{CF}$ and those from their healthy peers. This underlines that in spite of the problems associated with this disease, correct supplementation strategies and clinical care may counteract the possible detrimental consequences of $\mathrm{CF}$ on bone health during growth. In addition, long-term physical activity programs may further protect against the sequels of $\mathrm{CF}$ on bone mass. 



\section{References}

1. Shepherd R, Cooksley WG, Cooke WD. Improved growth and clinical, nutritional, and respiratory changes in response to nutritional therapy in cystic fibrosis. The Journal of pediatrics. 1980 Sep;97(3):351-7. PubMed PMID: 6774070.

2. Ubago-Guisado E, Vlachopoulos D, Fatouros IG, Deli CK, Leontsini D, Moreno LA, et al. Longitudinal determinants of 12-month changes on bone health in adolescent male athletes. Arch Osteoporos. 2018.

3. Aris RM, Renner JB, Winders AD, Buell HE, Riggs DB, Lester GE, et al. Increased rate of fractures and severe kyphosis: sequelae of living into adulthood with cystic fibrosis. Annals of internal medicine. 1998 Feb 1;128(3):186-93. PubMed PMID: 9454526.

4. Henderson RC, Specter BB. Kyphosis and fractures in children and young adults with cystic fibrosis. The Journal of pediatrics. 1994 Aug;125(2):208-12. PubMed PMID: 8040763.

5. Wolfenden LL, Judd SE, Shah R, Sanyal R, Ziegler TR, Tangpricha V. Vitamin D and bone health in adults with cystic fibrosis. Clinical endocrinology. 2008 Sep;69(3):374-81. PubMed PMID: 18284636. Pubmed Central PMCID: 2851223.

6. Ubago-Guisado E, Vlachopoulos D, Barker AR, Christoffersen T, Metcalf B, GraciaMarco L. Effect of maturational timing on bone health in male adolescent athletes engaged in different sports: The PRO-BONE study. Journal of science and medicine in sport. 2018 Aug 18. PubMed PMID: 30146475.

7. Peterson ML, Jacobs DR, Jr., Milla CE. Longitudinal changes in growth parameters are correlated with changes in pulmonary function in children with cystic fibrosis. Pediatrics. 2003 Sep;112(3 Pt 1):588-92. PubMed PMID: 12949289.

8. MacDonald A. Nutritional management of cystic fibrosis. Archives of disease in childhood. 1996 Jan;74(1):81-7. PubMed PMID: 8660059. Pubmed Central PMCID: 1511597.

9. Putman MS, Milliren CE, Derrico N, Uluer A, Sicilian L, Lapey A, et al. Compromised bone microarchitecture and estimated bone strength in young adults with cystic fibrosis. The Journal of clinical endocrinology and metabolism. 2014 Sep;99(9):3399-407. PubMed PMID: 24926955. Pubmed Central PMCID: 4154107.

10. Buntain HM, Greer RM, Schluter PJ, Wong JC, Batch JA, Potter JM, et al. Bone mineral density in Australian children, adolescents and adults with cystic fibrosis: a controlled cross sectional study. Thorax. 2004 Feb;59(2):149-55. PubMed PMID: 14760157. Pubmed Central PMCID: PMC1746947. Epub 2004/02/05. eng.

11. Sands D, Mielus M, Umlawska W, Lipowicz A, Oralewska B, Walkowiak J. Evaluation of factors related to bone disease in Polish children and adolescents with cystic fibrosis. Advances in medical sciences. 2015 Sep;60(2):315-20. PubMed PMID: 26183540. Epub 2015/07/18. eng.

12. Kelly A, Schall J, Stallings VA, Zemel BS. Trabecular and cortical bone deficits are present in children and adolescents with cystic fibrosis. Bone. 2016 Sep;90:7-14. PubMed PMID: 27143111. Epub 2016/05/05. eng.

13. Paccou J, Zeboulon N, Combescure C, Gossec L, Cortet B. The prevalence of osteoporosis, osteopenia, and fractures among adults with cystic fibrosis: a systematic literature review with meta-analysis. Calcified tissue international. 2010 Jan;86(1):1-7. PubMed PMID: 19949942. 
14. Baxter-Jones AD, Faulkner RA, Forwood MR, Mirwald RL, Bailey DA. Bone mineral accrual from 8 to 30 years of age: an estimation of peak bone mass. J Bone Miner Res. 2011 Aug;26(8):1729-39. PubMed PMID: 21520276. Epub 2011/04/27. eng.

15. Henry YM, Fatayerji D, Eastell R. Attainment of peak bone mass at the lumbar spine, femoral neck and radius in men and women: relative contributions of bone size and volumetric bone mineral density. Osteoporos Int. 2004 Apr;15(4):263-73. PubMed PMID: 14985946. Epub 2004/02/27. eng.

16. Aris RM, Merkel PA, Bachrach LK, Borowitz DS, Boyle MP, Elkin SL, et al. Guide to bone health and disease in cystic fibrosis. The Journal of clinical endocrinology and metabolism. 2005 Mar;90(3):1888-96. PubMed PMID: 15613415.

17. Stephenson A, Jamal S, Dowdell T, Pearce D, Corey M, Tullis E. Prevalence of vertebral fractures in adults with cystic fibrosis and their relationship to bone mineral density. Chest. 2006 Aug;130(2):539-44. PubMed PMID: 16899856.

18. Rossini M, Del Marco A, Dal Santo F, Gatti D, Braggion C, James G, et al. Prevalence and correlates of vertebral fractures in adults with cystic fibrosis. Bone. 2004 Sep;35(3):771-6. PubMed PMID: 15336615.

19. Bianchi ML, Romano G, Saraifoger S, Costantini D, Limonta C, Colombo C. BMD and body composition in children and young patients affected by cystic fibrosis. Journal of bone and mineral research : the official journal of the American Society for Bone and Mineral Research. 2006 Mar;21(3):388-96. PubMed PMID: 16491286. Epub 2006/02/24. eng.

20. Sermet-Gaudelus I, Souberbielle JC, Ruiz JC, Vrielynck S, Heuillon B, Azhar I, et al. Low bone mineral density in young children with cystic fibrosis. American journal of respiratory and critical care medicine. 2007 May 1;175(9):951-7. PubMed PMID: 17272788. Epub 2007/02/03. eng.

21. Bhudhikanok GS, Wang MC, Marcus R, Harkins A, Moss RB, Bachrach LK. Bone acquisition and loss in children and adults with cystic fibrosis: a longitudinal study. The Journal of pediatrics. 1998 Jul;133(1):18-27. PubMed PMID: 9672505. Epub 1998/07/22. eng.

22. Henderson RC, Madsen CD. Bone density in children and adolescents with cystic fibrosis. The Journal of pediatrics. 1996 Jan;128(1):28-34. PubMed PMID: 8551418. Epub 1996/01/01. eng.

23. Laursen EM, Molgaard C, Michaelsen KF, Koch C, Muller J. Bone mineral status in 134 patients with cystic fibrosis. Archives of disease in childhood. 1999 Sep;81(3):23540. PubMed PMID: 10451397. Pubmed Central PMCID: PMC1718073. Epub 1999/08/18. eng.

24. Legroux-Gerot I, Leroy S, Prudhomme C, Perez T, Flipo RM, Wallaert B, et al. Bone loss in adults with cystic fibrosis: prevalence, associated factors, and usefulness of biological markers. Joint, bone, spine : revue du rhumatisme. 2012 Jan;79(1):73-7. PubMed PMID: 21733729.

25. Donovan DS, Jr., Papadopoulos A, Staron RB, Addesso V, Schulman L, McGregor $C$, et al. Bone mass and vitamin $D$ deficiency in adults with advanced cystic fibrosis lung disease. American journal of respiratory and critical care medicine. 1998 Jun;157(6 Pt 1):1892-9. PubMed PMID: 9620924.

26. Reix P, Bellon G, Braillon P. Bone mineral and body composition alterations in paediatric cystic fibrosis patients. Pediatric radiology. 2010 Mar;40(3):301-8. PubMed PMID: 19956937. Epub 2009/12/04. eng. 
27. Paccou J, Fardellone P, Cortet B. Cystic fibrosis-related bone disease. Current opinion in pulmonary medicine. 2013 Nov;19(6):681-6. PubMed PMID: 24060979.

28. Marquette $M$, Haworth CS. Bone health and disease in cystic fibrosis. Paediatric respiratory reviews. 2016 Aug;20 Suppl:2-5. PubMed PMID: 27461283.

29. Jacquot J, Delion M, Gangloff S, Braux J, Velard F. Bone disease in cystic fibrosis: new pathogenic insights opening novel therapies. Osteoporosis international : a journal established as result of cooperation between the European Foundation for Osteoporosis and the National Osteoporosis Foundation of the USA. 2016 Apr;27(4):1401-12. PubMed PMID: 26431978.

30. Dimai HP. Use of dual-energy X-ray absorptiometry (DXA) for diagnosis and fracture risk assessment; WHO-criteria, $\mathrm{T}$ - and Z-score, and reference databases. Bone. 2016 Dec 29. PubMed PMID: 28041872.

31. Bachrach LK, Gordon CM, Section On E. Bone Densitometry in Children and Adolescents. Pediatrics. 2016 Oct;138(4). PubMed PMID: 27669735.

32. Lee WTK, Cheung AYK, Lau J, Lee SKM, Qin L, Cheng JCY. Bone densitometry: which skeletal sites are best predicted by bone mass determinants? Journal of Bone and Mineral Metabolism. 2004 Sep;22(5):447-55. PubMed PMID: WOS:000223352300006. English.

33. Stroup DF, Berlin JA, Morton SC, Olkin I, Williamson GD, Rennie D, et al. Metaanalysis of observational studies in epidemiology: a proposal for reporting. Metaanalysis Of Observational Studies in Epidemiology (MOOSE) group. JAMA. $2000 \mathrm{Apr}$ 19;283(15):2008-12. PubMed PMID: 10789670.

34. Higgins J, Deeks J. Selecting studies and collecting data. Cochrane Handbook of Systematic Reviews of Interventions. Higgins JPT, Green S. 2008. Version 5.1.0 (updated Mar 2011) ed: John Wiley \& Sons, Chichester, UK.

35. National Institutes of Health. Quality assessment tool for observational cohort and cross-sectional studies. Avaliable from: www. nhlbi. nih. gov/healthpro/guidelines/in-develop/cardiovascular-risk-reduction/tools/cohort. [Accessed October 10, 2018].2014.

36. Mantel N, Haenszel W. Statistical aspects of the analysis of data from retrospective studies of disease. Journal of the National Cancer Institute. 1959 Apr;22(4):719-48. PubMed PMID: 13655060.

37. Higgins JPT, Thompson SG. Quantifying heterogeneity in a meta-analysis. Statistics in Medicine. 2002 Jun 15;21(11):1539-58. PubMed PMID: WOS:000176016900005. English.

38. Sterne JA, Egger M, Smith GD. Systematic reviews in health care: Investigating and dealing with publication and other biases in meta-analysis. BMJ. 2001 Jul 14;323(7304):101-5. PubMed PMID: 11451790. Pubmed Central PMCID: 1120714.

39. Colombo C, Costantini D, Rocchi A, Romano G, Rossi G, Bianchi ML, et al. Effects of liver transplantation on the nutritional status of patients with cystic fibrosis. Transplant international : official journal of the European Society for Organ Transplantation. 2005 Feb;18(2):246-55. PubMed PMID: 15691279. Epub 2005/02/05. eng.

40. Hillman LS, Cassidy JT, Popescu MF, Hewett JE, Kyger J, Robertson JD. Percent true calcium absorption, mineral metabolism, and bone mineralization in children with cystic fibrosis: effect of supplementation with vitamin $D$ and calcium. Pediatric 
pulmonology. 2008 Aug;43(8):772-80. PubMed PMID: 18615666. Epub 2008/07/11. eng.

41. Schulze KJ, Cutchins C, Rosenstein BJ, Germain-Lee EL, O'Brien KO. Calcium acquisition rates do not support age-appropriate gains in total body bone mineral content in prepuberty and late puberty in girls with cystic fibrosis. Osteoporosis international : a journal established as result of cooperation between the European Foundation for Osteoporosis and the National Osteoporosis Foundation of the USA. 2006;17(5):731-40. PubMed PMID: 16505982. Epub 2006/03/01. eng.

42. Sharma S, Jaksic M, Fenwick S, Byrnes C, Cundy T. Accrual of Bone Mass in Children and Adolescents With Cystic Fibrosis. The Journal of clinical endocrinology and metabolism. 2017 May 1;102(5):1734-9. PubMed PMID: 28323913. Epub 2017/03/23. eng.

43. Ujhelyi R, Treszl A, Vasarhelyi B, Holics K, Toth M, Arato A, et al. Bone mineral density and bone acquisition in children and young adults with cystic fibrosis: a followup study. Journal of pediatric gastroenterology and nutrition. 2004 Apr;38(4):401-6. PubMed PMID: 15085018. Epub 2004/04/16. eng.

44. Agostinete RR, Lynch KR, Gobbo LA, Lima MC, Ito IH, Luiz-de-Marco R, et al. Basketball Affects Bone Mineral Density Accrual in Boys More Than Swimming and Other Impact Sports: 9-mo Follow-Up. J Clin Densitom. 2016 Jul-Sep;19(3):375-81. PubMed PMID: 27174316.

45. Ara I, Vicente-Rodríguez G, Pérez-Gómez J, Jiménez-Ramírez J, Serrano-Sánchez $J A$, Dorado $C$, et al. Influence of extracurricular sport activities on body composition and physical fitness in boys: a 3-year longitudinal study. International journal of obesity. 2006;30(7):1062-71.

46. Bonjour JP, Carrie AL, Ferrari S, Clavien H, Slosman D, Theintz G, et al. Calciumenriched foods and bone mass growth in prepubertal girls: a randomized, double-blind, placebo-controlled trial. The Journal of clinical investigation. 1997 Mar 15;99(6):128794. PubMed PMID: 9077538. Pubmed Central PMCID: 507944.

47. Cameron MA, Paton LM, Nowson CA, Margerison C, Frame M, Wark JD. The effect of calcium supplementation on bone density in premenarcheal females: a co-twin approach. The Journal of clinical endocrinology and metabolism. 2004 Oct;89(10):491622. PubMed PMID: 15472185.

48. Chevalley $\mathrm{T}$, Bonjour JP, Ferrari S, Rizzoli R. Pubertal timing and body mass index gain from birth to maturity in relation with femoral neck BMD and distal tibia microstructure in healthy female subjects. Osteoporosis international : a journal established as result of cooperation between the European Foundation for Osteoporosis and the National Osteoporosis Foundation of the USA. 2011 Oct;22(10):2689-98. PubMed PMID: 21359672. Pubmed Central PMCID: 3169779.

49. Erlandson MC, Kontulainen SA, Chilibeck PD, Arnold CM, Faulkner RA, BaxterJones AD. Higher premenarcheal bone mass in elite gymnasts is maintained into young adulthood after long-term retirement from sport: a 14-year follow-up. Journal of bone and mineral research : the official journal of the American Society for Bone and Mineral Research. 2012 Jan;27(1):104-10. PubMed PMID: 21956460.

50. Fuchs RK, Bauer JJ, Snow CM. Jumping improves hip and lumbar spine bone mass in prepubescent children: a randomized controlled trial. Journal of bone and mineral research : the official journal of the American Society for Bone and Mineral Research. 2001 Jan;16(1):148-56. PubMed PMID: 11149479. 
51. Gomez-Bruton A, Gonzalez-Aguero A, Matute-Llorente A, Gomez-Cabello A, Casajus JA, Vicente-Rodriguez $G$. Longitudinal effects of swimming on bone in adolescents: a pQCT and DXA study. Biology of sport. 2017 Dec;34(4):361-70. PubMed PMID: 29472739. Pubmed Central PMCID: 5819466.

52. Lambert HL, Eastell R, Karnik K, Russell JM, Barker ME. Calcium supplementation and bone mineral accretion in adolescent girls: an 18-mo randomized controlled trial with 2-y follow-up. The American journal of clinical nutrition. 2008 Feb;87(2):455-62. PubMed PMID: 18258639.

53. MacKelvie KJ, McKay HA, Petit MA, Moran O, Khan KM. Bone mineral response to a 7-month randomized controlled, school-based jumping intervention in 121 prepubertal boys: Associations with ethnicity and body mass index. Journal of Bone and Mineral Research. 2002 May;17(5):834-44. PubMed PMID: WOS:000175229100011. English.

54. Markovic V, Goel PK, Badenhop-Stevens NE, Landoll JD, Li B, Ilich JZ, et al. Calcium supplementation and bone mineral density in females from childhood to young adulthood: a randomized controlled trial. American Journal of Clinical Nutrition. 2005 Jan;81(1):175-88. PubMed PMID: WOS:000226259800028. English.

55. Nickols-Richardson SM, O'Connor PJ, Shapses SA, Lewis RD. Longitudinal bone mineral density changes in female child artistic gymnasts. Journal of Bone and Mineral Research. 1999 Jun;14(6):994-1002. PubMed PMID: WOS:000080615500019. English.

56. Vaitkeviciute $D$, Lätt E, Mäestu J, Jürimäe $T$, Saar $M$, Purge $P$, et al. Longitudinal associations between bone and adipose tissue biochemical markers with bone mineralization in boys during puberty. BMC pediatrics. 2016 07/20

$11 / 26 /$ received

07/15/accepted;16:102. PubMed PMID: PMC4955269.

57. Bradney M, Pearce G, Naughton G, Sullivan C, Bass S, Beck T, et al. Moderate exercise during growth in prepubertal boys: changes in bone mass, size, volumetric density, and bone strength: a controlled prospective study. Journal of bone and mineral research : the official journal of the American Society for Bone and Mineral Research. 1998 Dec;13(12):1814-21. PubMed PMID: 9844098.

58. Johannsen N, Binkley T, Englert V, Neiderauer G, Specker B. Bone response to jumping is site-specific in children: a randomized trial. Bone. 2003 Oct;33(4):533-9. PubMed PMID: 14555256.

59. Laing EM, Wilson AR, Modlesky CM, O'Connor PJ, Hall DB, Lewis RD. Initial years of recreational artistic gymnastics training improves lumbar spine bone mineral accrual in 4- to 8-year-old females. Journal of bone and mineral research : the official journal of the American Society for Bone and Mineral Research. 2005 Mar;20(3):509-19. PubMed PMID: 15746997.

60. Linden C, Ahlborg HG, Besjakov J, Gardsell P, Karlsson MK. A school curriculumbased exercise program increases bone mineral accrual and bone size in prepubertal girls: two-year data from the pediatric osteoporosis prevention (POP) study. Journal of bone and mineral research : the official journal of the American Society for Bone and Mineral Research. 2006 Jun;21(6):829-35. PubMed PMID: 16753013.

61. Mackelvie KJ, McKay HA, Khan KM, Crocker PR. A school-based exercise intervention augments bone mineral accrual in early pubertal girls. The Journal of pediatrics. 2001 Oct;139(4):501-8. PubMed PMID: 11598595. 
62. McKay HA, Petit MA, Schutz RW, Prior JC, Barr SI, Khan KM. Augmented trochanteric bone mineral density after modified physical education classes: a randomized school-based exercise intervention study in prepubescent and early pubescent children. The Journal of pediatrics. 2000 Feb;136(2):156-62. PubMed PMID: 10657819.

63. Morris FL, Naughton GA, Gibbs JL, Carlson JS, Wark JD. Prospective ten-month exercise intervention in premenarcheal girls: positive effects on bone and lean mass. Journal of bone and mineral research : the official journal of the American Society for Bone and Mineral Research. 1997 Sep;12(9):1453-62. PubMed PMID: 9286762.

64. Nichols DL, Sanborn CF, Love AM. Resistance training and bone mineral density in adolescent females. The Journal of pediatrics. 2001 Oct;139(4):494-500. PubMed PMID: 11598594.

65. Van Langendonck L, Claessens AL, Vlietinck R, Derom C, Beunen G. Influence of weight-bearing exercises on bone acquisition in prepubertal monozygotic female twins: a randomized controlled prospective study. Calcified tissue international. 2003 Jun;72(6):666-74. PubMed PMID: 14562994.

66. Chevalley T, Bonjour JP, van Rietbergen B, Ferrari S, Rizzoli R. Fractures during childhood and adolescence in healthy boys: relation with bone mass, microstructure, and strength. The Journal of clinical endocrinology and metabolism. 2011 Oct;96(10):3134-42. PubMed PMID: 21795454. Epub 2011/07/29. eng.

67. Gustavsson A, Thorsen K, Nordström P. A 3-year longitudinal study of the effect of physical activity on the accrual of bone mineral density in healthy adolescent males. Calcified Tissue International. 2003;73(2):108-14.

68. Katzman DK, Bachrach LK, Carter DR, Marcus R. Clinical and anthropometric correlates of bone mineral acquisition in healthy adolescent girls. The Journal of clinical endocrinology and metabolism. 1991 Dec;73(6):1332-9. PubMed PMID: 1955516. Epub 1991/12/01. eng.

69. Maggio ABR, Rizzoli RR, Marchand LM, Ferrari S, Beghetti M, Farpour-Lambert NJ. Physical activity increases bone mineral density in children with type 1 diabetes. Medicine and Science in Sports and Exercise 2012 Jul;44(7):1206-1211. 2012. English.

70. Molgaard C, Larnkjaer A, Cashman KD, Lamberg-Allardt C, Jakobsen J, Michaelsen KF. Does vitamin D supplementation of healthy Danish Caucasian girls affect bone turnover and bone mineralization? Bone. 2010 Feb;46(2):432-9. PubMed PMID: 19735754. Epub 2009/09/09. eng.

71. Nogueira RC, Weeks BK, Beck BR. Targeting bone and fat with novel exercise for peripubertal boys: the CAPO kids trial. Pediatric Exercise Science. 2015;27(1):128-39. English.

72. Zouch M, Zribi A, Alexandre C, Chaari H, Frere D, Tabka Z, et al. Soccer increases bone mass in prepubescent boys during growth: a 3-yr longitudinal study. Journal of Clinical Densitometry. 2015 Apr-Jun;18(2):179-86. PubMed PMID: 25592396.

73. National Institutes of Health. Quality assessment tool for observational cohort and cross-sectional studies. National Heart, Lung, and Blood Institute Avaliable from: www nhlbi nih gov/health-pro/guidelines/indevelop/cardiovascular-riskreduction/tools/cohort [Accessed October 10, 2018]. 2014.

74. King SJ, Topliss DJ, Kotsimbos T, Nyulasi IB, Bailey M, Ebeling PR, et al. Reduced bone density in cystic fibrosis: DeltaF508 mutation is an independent risk factor. The European respiratory journal. 2005 Jan;25(1):54-61. PubMed PMID: 15640323. 
75. Elkin SL, Vedi S, Bord S, Garrahan NJ, Hodson ME, Compston JE. Histomorphometric analysis of bone biopsies from the iliac crest of adults with cystic fibrosis. American journal of respiratory and critical care medicine. 2002 Dec 1;166(11):1470-4. PubMed PMID: 12406824.

76. Conwell LS, Chang AB. Bisphosphonates for osteoporosis in people with cystic fibrosis. The Cochrane database of systematic reviews. 2014 Mar 14(3):CD002010. PubMed PMID: 24627308.

77. Mackelvie KJ, Khan KM, McKay HA. Is there a critical period for bone response to weight-bearing exercise in children and adolescents? a systematic review. Br J Sports Med. 2002;36(4):250-7.

78. Ubago-Guisado E, Gómez-Cabello A, Sánchez-Sánchez J, García-Unanue J, Gallardo L. Influence of different sports on bone mass in growing girls. J Sports Sci Med. 2015;33(16):1710-8.

79. Vlachopoulos D, Barker AR, Williams CA, SA AR, Knapp KM, Metcalf BS, et al. The Impact of Sport Participation on Bone Mass and Geometry in Male Adolescents. Med Sci Sports Exerc. 2017 Feb;49(2):317-26. PubMed PMID: 27631395. Epub 2016/09/16.

80. Nikander R, Sievanen H, Heinonen A, Daly RM, Uusi-Rasi K, Kannus P. Targeted exercise against osteoporosis: A systematic review and meta-analysis for optimising bone strength throughout life. BMC Med. 2010;8:47. PubMed PMID: 20663158. Pubmed Central PMCID: PMC2918523. English.

81. Sermet-Gaudelus I, Bianchi ML, Garabedian M, Aris RM, Morton A, Hardin DS, et al. European cystic fibrosis bone mineralisation guidelines. Journal of cystic fibrosis : official journal of the European Cystic Fibrosis Society. 2011 Jun;10 Suppl 2:S16-23. PubMed PMID: 21658635. 


\begin{tabular}{|c|c|c|c|c|c|c|c|c|c|c|c|}
\hline \multirow[b]{2}{*}{ Study (year) } & \multirow[b]{2}{*}{ Country } & \multirow[b]{2}{*}{ Study design } & \multicolumn{6}{|c|}{ Population characteristics at baseline } & \multicolumn{3}{|c|}{ Outcome } \\
\hline & & & $\begin{array}{c}\text { Age } \\
\text { [years (mean } \\
\pm \mathrm{SD})]\end{array}$ & $\begin{array}{l}\text { Sample size } \\
{[\mathrm{n}(\% \text { male })]}\end{array}$ & $\begin{array}{c}\text { BMI } \\
{\left[\mathrm{kg} / \mathrm{m}^{2}(\text { mean }\right.} \\
\pm \mathrm{SD})] \\
\end{array}$ & $\begin{array}{c}\text { Stature } \\
{[\mathrm{cm}(\text { mean }} \\
\pm \mathrm{SD})] \\
\end{array}$ & $\begin{array}{c}\text { Weight } \\
{[\mathrm{kg}(\text { mean }} \\
\pm \mathrm{SD})] \\
\end{array}$ & $\begin{array}{c}\text { Type of } \\
\text { population }\end{array}$ & Method & Baseline bone & Follow-up bone \\
\hline $\begin{array}{l}\text { Bhudhikanok } \\
\text { et al. (1998) }\end{array}$ & USA & $\begin{array}{l}\text { Longitudinal } \\
\text { study } \\
\text { (1.5 years) }\end{array}$ & $\begin{array}{l}\frac{\text { Males }}{11.8 \pm 2.7} \\
\frac{\text { Females }}{12.1 \pm 2.7}\end{array}$ & $20(45 \%)$ & $\begin{array}{l}\frac{\text { Males }}{18.5 \pm 3.0} \\
\frac{\text { Females }}{16.2 \pm 2.3}\end{array}$ & $\begin{array}{l}\frac{\text { Males }}{146 \pm 18} \\
\frac{\text { Females }}{145 \pm 15}\end{array}$ & $\begin{array}{l}\frac{\text { Males }}{41.0 \pm 16.4} \\
\frac{\text { Females }}{35.1 \pm 11.2}\end{array}$ & $\begin{array}{l}\text { Patients with } \\
\text { cystic fibrosis }\end{array}$ & $\begin{array}{l}\text { Hologic QDR } \\
\text { 1000W dual- } \\
\text { energy x-ray } \\
\text { absorptiometry } \\
\text { scanner (Hologic } \\
\text { Corporation, } \\
\text { Waltham, Mass) }\end{array}$ & $\begin{array}{l}\frac{\underline{\text { Males }}}{\underline{(\text { mean }} \pm \mathrm{SD}):} \\
\text { WB BMD }\left(\mathrm{g} / \mathrm{cm}^{2}\right): \\
0.855 \pm 0.106 \\
\mathrm{LS} \mathrm{BMD}\left(\mathrm{g} / \mathrm{cm}^{2}\right): \\
0.661 \pm 0.140 \\
\text { FN BMD }\left(\mathrm{g} / \mathrm{cm}^{2}\right): \\
0.706 \pm 0.114 \\
\\
\underline{\text { Females }} \\
\underline{(\text { mean } \pm S D):} \\
\text { WB BMD }\left(\mathrm{g} / \mathrm{cm}^{2}\right): \\
0.815 \pm 0.133 \\
\text { LS BMD }\left(\mathrm{g} / \mathrm{cm}^{2}\right): \\
0.704 \pm 0.210 \\
\text { FN BMD }\left(\mathrm{g} / \mathrm{cm}^{2}\right): \\
0.616 \pm 0.146\end{array}$ & $\begin{array}{l}\frac{\text { Males }}{(\text { mean } \pm \mathrm{SD}):} \\
\text { WB BMD }\left(\mathrm{g} / \mathrm{cm}^{2}\right): \\
0.864 \pm 0.103 \\
\text { LS BMD }\left(\mathrm{g} / \mathrm{cm}^{2}\right): \\
0.678 \pm 0.116 \\
\text { FN BMD }\left(\mathrm{g} / \mathrm{cm}^{2}\right): \\
0.718 \pm 0.113 \\
\\
\underline{\text { Females }} \\
\underline{(\text { mean } \pm S D):} \\
\text { WB BMD }\left(\mathrm{g} / \mathrm{cm}^{2}\right): \\
0.829 \pm 0.144 \\
\text { LS BMD }\left(\mathrm{g} / \mathrm{cm}^{2}\right): \\
0.731 \pm 0.227 \\
\text { FN BMD }\left(\mathrm{g} / \mathrm{cm}^{2}\right): \\
0.637 \pm 0.182\end{array}$ \\
\hline $\begin{array}{l}\text { Colombo et } \\
\text { al. }(2005)\end{array}$ & Italy & $\begin{array}{l}\text { Longitudinal } \\
\text { study } \\
\text { (5 years) }\end{array}$ & $11.5 \pm 1.6$ & $4(75 \%)$ & $16.9 \pm 2.1$ & $142.0 \pm 5.0$ & $34.0 \pm 4.0$ & $\begin{array}{l}\text { Liver transplant } \\
\text { patients with } \\
\text { cystic fibrosis }\end{array}$ & $\begin{array}{l}\text { Hologic QDR } \\
2000 \text { dual-energy } \\
\text { X-ray } \\
\text { absorptiometry } \\
\text { scanner (Hologic } \\
\text { Inc., Bedford, } \\
\text { MA, USA). } \\
\end{array}$ & $\begin{array}{l}(\text { Mean } \pm \text { SD }): \\
\text { WB BMD }\left(\mathrm{g} / \mathrm{cm}^{2}\right) \\
0.810 \pm 0.122\end{array}$ & $\begin{array}{l}\frac{(\text { Mean } \pm \mathrm{SD}):}{\text { WB BMD }\left(\mathrm{g} / \mathrm{cm}^{2}\right)}: \\
0.880 \pm 0.106\end{array}$ \\
\hline $\begin{array}{l}\text { Colombo et } \\
\text { al. (2005) }\end{array}$ & Italy & $\begin{array}{l}\text { Longitudinal } \\
\text { study } \\
\text { (4.6 years) }\end{array}$ & $11.9 \pm 4.4$ & $5(60 \%)$ & $17.0 \pm 2.5$ & $141.0 \pm 22.6$ & $37.9 \pm 12.8$ & $\begin{array}{l}\text { Nontransplante } \\
\text { d patients with } \\
\text { cystic fibrosis }\end{array}$ & $\begin{array}{l}\text { Hologic QDR } \\
\text { 2000 dual-energy } \\
\text { X-ray } \\
\text { absorptiometry } \\
\text { scanner (Hologic } \\
\text { Inc., Bedford, } \\
\text { MA, USA). }\end{array}$ & $\begin{array}{l}\frac{(\text { Mean } \pm \text { SD }):}{\text { WB BMD }\left(\mathrm{g} / \mathrm{cm}^{2}\right)} \\
0.854 \pm 0.073\end{array}$ & $\begin{array}{l}\frac{(\text { Mean } \pm \text { SD }):}{\text { WB BMD }\left(\mathrm{g} / \mathrm{cm}^{2}\right)}: \\
0.906 \pm 0.078\end{array}$ \\
\hline $\begin{array}{l}\text { Hillman et al. } \\
(2008)\end{array}$ & USA & $\begin{array}{l}\text { Longitudinal } \\
\text { study }\end{array}$ & $9.1 \pm 2.3$ & 9 (NR) & $15.9 \pm 1.1$ & $134 \pm 14$ & $29.3 \pm 7.5$ & $\begin{array}{l}\text { Patients with } \\
\text { cystic fibrosis }\end{array}$ & $\begin{array}{l}\text { Hologic 1000W } \\
\text { dual-energy x- }\end{array}$ & $\frac{\text { Changes }}{(\text { mean } \pm S D):}$ & \\
\hline
\end{tabular}




\begin{tabular}{|c|c|c|c|c|c|c|c|c|c|c|c|}
\hline & & (9 months) & $\begin{array}{l}\text { (pero es de } \\
\text { todos los } \\
\text { sujetos, ya } \\
\text { que no } \\
\text { muestran la } \\
\text { edad sólo del } \\
\text { grupo } \\
\text { placebo) }\end{array}$ & & $\begin{array}{l}\text { (igual que } \\
\text { con la edad) }\end{array}$ & \begin{tabular}{|l} 
(igual que \\
con la edad)
\end{tabular} & \begin{tabular}{|l|} 
(igual que \\
con la edad)
\end{tabular} & & $\begin{array}{l}\text { ray } \\
\text { absorptiometry } \\
\text { scanner }\end{array}$ & $\begin{array}{l}\text { WB BMD }\left(\mathrm{g} / \mathrm{cm}^{2}\right): \\
0.033 \pm 0.027 \\
\text { LS BMD }\left(\mathrm{g} / \mathrm{cm}^{2}\right) \\
0.041 \pm 0.045\end{array}$ & \\
\hline $\begin{array}{l}\text { Schulze et al. } \\
\text { (2006) }\end{array}$ & USA & $\begin{array}{l}\text { Longitudinal } \\
\text { study } \\
\text { (1-4 years) }\end{array}$ & $12.1 \pm 3.2$ & $18(0 \%)$ & $18.0 \pm 3.0$ & $146 \pm 15$ & $39.6 \pm 13.9$ & $\begin{array}{l}\text { Patients with } \\
\text { cystic fibrosis }\end{array}$ & $\begin{array}{l}\text { Hologic QDR- } \\
\text { 4500A dual- } \\
\text { energy x-ray } \\
\text { absorptiometry } \\
\text { scanner }\end{array}$ & $\begin{array}{l}\frac{Z \text {-score }}{(\text { mean } \pm \text { SD): }} \\
\text { LS BMD: } \\
-0.40 \pm 1.13\end{array}$ & $\begin{array}{l}\frac{\text { Z-score }}{(\text { mean } \pm \text { SD): }} \\
\text { LS BMD: } \\
-0.46 \pm 0.94\end{array}$ \\
\hline $\begin{array}{l}\text { Sharma et al. } \\
\text { (2017) }\end{array}$ & $\begin{array}{l}\text { New } \\
\text { Zealand }\end{array}$ & $\begin{array}{l}\text { Longitudinal } \\
\text { study } \\
\text { (2 years) }\end{array}$ & $12.1 \pm 2.0$ & $40(0 \%)$ & $\begin{array}{l}\text { Z-score: } \\
-0.17 \pm 1.05\end{array}$ & $\begin{array}{l}\text { Z-score: } \\
-0.49 \pm 0.88\end{array}$ & $\begin{array}{l}\text { Z-score: } \\
-0.36 \pm 0.93\end{array}$ & $\begin{array}{l}\text { Patients with } \\
\text { cystic fibrosis }\end{array}$ & $\begin{array}{l}\text { Lunar Prodigy } \\
\text { dual-energy x- } \\
\text { ray } \\
\text { absorptiometry } \\
\text { scanner (GE } \\
\text { Health } \\
\text { Care) }\end{array}$ & $\begin{array}{l}\frac{Z \text {-score }}{(\text { mean } \pm \text { SD): }} \\
\text { LS BMD: } \\
-0.94 \pm 0.88\end{array}$ & $\begin{array}{l}\frac{Z \text {-score }}{(\text { mean } \pm \text { SD) }} \\
\text { LS BMD: } \\
-1.13 \pm 1.0\end{array}$ \\
\hline $\begin{array}{l}\text { Ujhelyi et al. } \\
\text { (2004) }\end{array}$ & Hungary & $\begin{array}{l}\text { Longitudinal } \\
\text { study } \\
\text { (2 years) }\end{array}$ & $8.3(4-12)$ & $11(63.6 \%)$ & NR & $115.1 \pm 9.1$ & $19.5 \pm 4.7$ & $\begin{array}{l}\text { Patients with } \\
\text { cystic fibrosis }\end{array}$ & $\begin{array}{l}\text { Dual x-ray } \\
\text { absorptiometry } \\
\text { (Hologic QDR } \\
\text { 4500C, Hologic, } \\
\text { Waltham, MA, } \\
\text { U.S.A.) }\end{array}$ & $\begin{array}{l}\frac{\text { Changes }}{(\text { mean } \pm S D):} \\
\text { LS BMD }\left(\mathrm{g} / \mathrm{cm}^{2}\right) \\
0.04 \pm 0.04 \\
\text { FN BMD }\left(\mathrm{g} / \mathrm{cm}^{2}\right) \\
0.08 \pm 0.06\end{array}$ & \\
\hline $\begin{array}{l}\text { Ujhelyi et al. } \\
\text { (2004) }\end{array}$ & Hungary & $\begin{array}{l}\text { Longitudinal } \\
\text { study } \\
\text { (2 years) }\end{array}$ & $14.9(8-19)$ & $16(56.3 \%)$ & NR & $149.0 \pm 16.9$ & $37.0 \pm 11.8$ & $\begin{array}{l}\text { Patients with } \\
\text { cystic fibrosis }\end{array}$ & $\begin{array}{l}\text { Dual x-ray } \\
\text { absorptiometry } \\
\text { (Hologic QDR } \\
\text { 4500C, Hologic, } \\
\text { Waltham, MA, } \\
\text { U.S.A.) }\end{array}$ & $\begin{array}{l}\frac{\text { Changes }}{(\text { mean } \pm S D):} \\
\text { LS BMD }\left(\mathrm{g} / \mathrm{cm}^{2}\right) \\
0.10 \pm 0.07 \\
\text { FN BMD }\left(\mathrm{g} / \mathrm{cm}^{2}\right) \\
0.07 \pm 0.07\end{array}$ & \\
\hline
\end{tabular}




\begin{tabular}{|c|c|c|c|c|c|c|c|c|c|c|c|}
\hline \multirow[b]{2}{*}{ Study (year) } & \multirow[b]{2}{*}{ Country } & \multirow[b]{2}{*}{$\begin{array}{l}\text { Study } \\
\text { design }\end{array}$} & \multicolumn{6}{|c|}{ Population characteristics (baseline) } & \multicolumn{3}{|c|}{ Outcome } \\
\hline & & & $\begin{array}{c}\text { Age } \\
\text { [years (mean } \\
\pm \text { SD)] }\end{array}$ & $\begin{array}{l}\text { Sample size } \\
{[\mathrm{n}(\% \text { male })]}\end{array}$ & $\begin{array}{c}\text { BMI } \\
{\left[\mathrm{kg} / \mathrm{m}^{2}(\text { mean }\right.} \\
\pm \mathrm{SD})]\end{array}$ & $\begin{array}{l}\text { Stature } \\
{[\mathrm{cm}(\text { mean }} \\
\pm \mathrm{SD})]\end{array}$ & $\begin{array}{l}\text { Weight } \\
{[\mathrm{kg}(\text { mean }} \\
\pm \mathrm{SD})]\end{array}$ & $\begin{array}{c}\text { Type of } \\
\text { population }\end{array}$ & Method & Baseline bone & Follow-up bone \\
\hline $\begin{array}{l}\text { Agostinete et } \\
\text { al. (2016) }\end{array}$ & Brazil & $\begin{array}{l}\text { A 9-mo } \\
\text { follow-up }\end{array}$ & $11.9 \pm 2.2$ & $13(100 \%)$ & NR & $154.5 \pm 13.1$ & NR & $\begin{array}{l}\text { Healthy male } \\
\text { adolescents }\end{array}$ & $\begin{array}{l}\text { Lunar DPX-NT } \\
\text { dual-energy x- } \\
\text { ray } \\
\text { absorptiometry } \\
\text { scanner }\end{array}$ & $\begin{array}{l}\text { Mean } \pm \text { SD: } \\
\text { WB BMD }\left(\mathrm{g} / \mathrm{cm}^{2}\right): \\
1.001 \pm 0.100 \\
\text { LS BMD }\left(\mathrm{g} / \mathrm{cm}^{2}\right) \\
0.857 \pm 0.130\end{array}$ & $\begin{array}{l}\text { Mean } \pm \text { SD: } \\
\text { WB BMD }\left(\mathrm{g} / \mathrm{cm}^{2}\right) \\
1.041 \pm 1.106 \\
\text { LS BMD }\left(\mathrm{g} / \mathrm{cm}^{2}\right) \\
0.901 \pm 0.147\end{array}$ \\
\hline $\begin{array}{l}\text { Ara et al. } \\
(2006)\end{array}$ & Spain & $\begin{array}{l}\text { 3.3-year } \\
\text { follow-up } \\
\text { period }\end{array}$ & $9.3 \pm 1.6$ & $16(100 \%)$ & $16.9 \pm 2.2$ & $136.5 \pm 10.8$ & $31.9 \pm 7.6$ & $\begin{array}{l}\text { Healthy male } \\
\text { children and } \\
\text { adolescents }\end{array}$ & $\begin{array}{l}\text { Hologic QDR- } \\
1500 \text { dual-energy } \\
\text { X-ray } \\
\text { absorptiometry } \\
\text { scanner }\end{array}$ & $\begin{array}{l}\text { Changes }(\text { mean } \pm \\
\text { SD): } \\
\text { WB BMD }\left(\mathrm{g} / \mathrm{cm}^{2}\right) \\
9.25 \pm 4.34\end{array}$ & \\
\hline $\begin{array}{l}\text { Bonjour et al. } \\
\text { (1997) }\end{array}$ & Switzerland & $\begin{array}{l}48 \text { wk } \\
\text { follow-up }\end{array}$ & $7.9 \pm 0.1$ & $53(0 \%)$ & $16.6 \pm 0.3$ & $127.2 \pm 0.8$ & $26.9 \pm 0.6$ & $\begin{array}{l}\text { Healthy } \\
\text { prepubertal } \\
\text { caucasian girls }\end{array}$ & $\begin{array}{l}\text { Hologic QDR- } \\
2000 \text { dual-energy } \\
\text { X-ray } \\
\text { absorptiometry } \\
\text { scanner }\end{array}$ & $\begin{array}{l}\text { Mean } \pm \text { SEM: } \\
\text { LS BMD }\left(\mathrm{g} / \mathrm{cm}^{2}\right) \\
0.615 \pm 0.008 \\
\text { FN BMD }\left(\mathrm{g} / \mathrm{cm}^{2}\right) \\
0.622 \pm 0.009\end{array}$ & $\begin{array}{l}\text { Mean } \pm \text { SEM: } \\
\text { LS BMD }\left(\mathrm{g} / \mathrm{cm}^{2}\right): \\
0.638 \pm 0.008 \\
\text { FN BMD }\left(\mathrm{g} / \mathrm{cm}^{2}\right) \\
0.635 \pm 0.009\end{array}$ \\
\hline $\begin{array}{l}\text { Cameron et } \\
\text { al. (2004) }\end{array}$ & Australia & $\begin{array}{l}\text { A 6-mo } \\
\text { follow-up }\end{array}$ & $10.3 \pm 1.5$ & $51(0 \%)$ & NR & $141.62 \pm 9.45$ & $37.5 \pm 9.5$ & $\begin{array}{l}\text { Healthy } \\
\text { australian } \\
\text { Twins }\end{array}$ & $\begin{array}{l}\text { QDR 1000W } \\
\text { dual-energy x- } \\
\text { ray } \\
\text { absorptiometry } \\
\text { scanner }\end{array}$ & $\begin{array}{l}\text { Mean } \pm \text { SD: } \\
\text { LS BMD }\left(\mathrm{g} / \mathrm{cm}^{2}\right) \\
0.697 \pm 0.085 \\
\text { FN BMD }\left(\mathrm{g} / \mathrm{cm}^{2}\right) \\
0.697 \pm 0.084\end{array}$ & $\begin{array}{l}\text { Mean } \pm \text { SD: } \\
\text { LS BMD }\left(\mathrm{g} / \mathrm{cm}^{2}\right) \\
0.724 \pm 0.097 \\
\text { FN BMD }\left(\mathrm{g} / \mathrm{cm}^{2}\right) \\
0.714 \pm 0.615\end{array}$ \\
\hline $\begin{array}{l}\text { Cameron et } \\
\text { al. (2004) } \\
\text { Mismo } \\
\text { estudio que el } \\
\text { anterior }\end{array}$ & Australia & $\begin{array}{l}\text { A 12-mo } \\
\text { follow-up }\end{array}$ & $10.4 \pm 1.5$ & $48(0 \%)$ & NR & $141.60 \pm 9.52$ & 37. \pm 9.8 & $\begin{array}{l}\text { Healthy } \\
\text { australian } \\
\text { Twins }\end{array}$ & $\begin{array}{l}\text { QDR 1000W } \\
\text { dual-energy x- } \\
\text { ray } \\
\text { absorptiometry } \\
\text { scanner } \\
\end{array}$ & $\begin{array}{l}\text { Mean } \pm \text { SD: } \\
\text { LS BMD }\left(\mathrm{g} / \mathrm{cm}^{2}\right) \\
0.697 \pm 0.085 \\
\text { FN BMD }\left(\mathrm{g} / \mathrm{cm}^{2}\right) \\
0.697 \pm 0.084\end{array}$ & $\begin{array}{l}\text { Mean } \pm \text { SD: } \\
\text { LS BMD }\left(\mathrm{g} / \mathrm{cm}^{2}\right) \\
0.759 \pm 0.114 \\
\text { FN BMD }\left(\mathrm{g} / \mathrm{cm}^{2}\right) \\
0.742 \pm 0.107\end{array}$ \\
\hline $\begin{array}{l}\text { Cameron et } \\
\text { al. (2004) } \\
\text { Mismo } \\
\text { estudio que el } \\
\text { anterior }\end{array}$ & Australia & $\begin{array}{l}\text { A 18-mo } \\
\text { follow-up }\end{array}$ & $10.4 \pm 1.5$ & $42(0 \%)$ & NR & $142.12 \pm 9.18$ & $37.6 \pm 9.5$ & $\begin{array}{l}\text { Healthy } \\
\text { australian } \\
\text { Twins }\end{array}$ & $\begin{array}{l}\text { QDR 1000W } \\
\text { dual-energy x- } \\
\text { ray } \\
\text { absorptiometry } \\
\text { scanner } \\
\end{array}$ & $\begin{array}{l}\text { Mean } \pm \text { SD: } \\
\text { LS BMD }\left(\mathrm{g} / \mathrm{cm}^{2}\right) \\
0.697 \pm 0.085 \\
\text { FN BMD }\left(\mathrm{g} / \mathrm{cm}^{2}\right) \\
0.697 \pm 0.084\end{array}$ & $\begin{array}{l}\text { Mean } \pm \text { SD: } \\
\text { LS BMD }\left(\mathrm{g} / \mathrm{cm}^{2}\right) \\
0.804 \pm 0.129 \\
\text { FN BMD }\left(\mathrm{g} / \mathrm{cm}^{2}\right) \\
0.765 \pm 0.112\end{array}$ \\
\hline
\end{tabular}




\begin{tabular}{|c|c|c|c|c|c|c|c|c|c|c|c|}
\hline $\begin{array}{l}\text { Cameron et } \\
\text { al. (2004) } \\
\text { Mismo } \\
\text { estudio que el } \\
\text { anterior }\end{array}$ & Australia & $\begin{array}{l}\text { A 24-mo } \\
\text { follow-up }\end{array}$ & $10.6 \pm 1.5$ & $24(0 \%)$ & NR & $141.80 \pm 9.12$ & $37.1 \pm 7.3$ & $\begin{array}{l}\text { Healthy } \\
\text { australian } \\
\text { Twins }\end{array}$ & $\begin{array}{l}\text { QDR 1000W } \\
\text { dual-energy x- } \\
\text { ray } \\
\text { absorptiometry } \\
\text { scanner } \\
\end{array}$ & $\begin{array}{l}\text { Mean } \pm \text { SD: } \\
\text { LS BMD }\left(\mathrm{g} / \mathrm{cm}^{2}\right) \\
0.697 \pm 0.085 \\
\text { FN BMD }\left(\mathrm{g} / \mathrm{cm}^{2}\right) \\
0.697 \pm 0.084\end{array}$ & $\begin{array}{l}\text { Mean } \pm \text { SD: } \\
\text { LS BMD }\left(\mathrm{g} / \mathrm{cm}^{2}\right): \\
0.833 \pm 0.142 \\
\text { FN BMD }\left(\mathrm{g} / \mathrm{cm}^{2}\right) \\
0.816 \pm 0.131\end{array}$ \\
\hline $\begin{array}{l}\text { Chevalley et } \\
\text { al. (2011) }\end{array}$ & Switzerland & $\begin{array}{l}\text { A 12-y } \\
\text { follow-up }\end{array}$ & $7.9 \pm 0.5$ & $124(0 \%)$ & $16.2 \pm 1.8$ & $127.7 \pm 5.9$ & $26.5 \pm 4.1$ & Healthy girls & $\begin{array}{l}\text { Hologic QDR- } \\
4500 \text { dual-energy } \\
\text { X-ray } \\
\text { absorptiometry } \\
\text { scanner }\end{array}$ & $\begin{array}{l}\text { Mean } \pm \text { SD: } \\
\text { FN BMD }\left(\mathrm{g} / \mathrm{cm}^{2}\right) \\
0.634 \pm 0.074\end{array}$ & $\begin{array}{l}\text { Mean } \pm \text { SD: } \\
\begin{array}{l}\text { FN BMD }\left(\mathrm{g} / \mathrm{cm}^{2}\right) \\
(\text { after } 1 \text { year })\end{array} \\
0.647 \pm 0.075 \\
\text { FN BMD }\left(\mathrm{g} / \mathrm{cm}^{2}\right) \\
(\text { after } 2 \text { years }) \\
0.675 \pm 0.078 \\
\text { FN BMD }\left(\mathrm{g} / \mathrm{cm}^{2}\right) \text { : } \\
(\text { after } 4 \text { years }) \\
0.751 \pm 0.103 \\
\text { FN BMD }\left(\mathrm{g} / \mathrm{cm}^{2}\right): \\
(\text { after } 8 \text { years }) \\
0.867 \pm 0.111 \\
\text { FN BMD }\left(\mathrm{g} / \mathrm{cm}^{2}\right): \\
(\text { after } 12 \text { years }) \\
0.858 \pm 0.108\end{array}$ \\
\hline $\begin{array}{l}\text { Erlandsson et } \\
\text { al. (2012) }\end{array}$ & Canada & $\begin{array}{l}\text { A 14-y } \\
\text { follow-up }\end{array}$ & $11.9 \pm 1.7$ & $22(0 \%)$ & NR & $151.6 \pm 11.7$ & $44.3 \pm 11.9$ & $\begin{array}{l}\text { Healthy white } \\
\text { girls }\end{array}$ & $\begin{array}{l}\text { Hologic } 2000 \\
\text { QDR dual- } \\
\text { energy x-ray } \\
\text { absorptiometry } \\
\text { scanner }\end{array}$ & $\begin{array}{l}\text { Mean } \pm \text { SD: } \\
\text { WB BMD }\left(\mathrm{g} / \mathrm{cm}^{2}\right) \\
0.8 \pm 0.1 \\
\text { LS BMD }\left(\mathrm{g} / \mathrm{cm}^{2}\right) \\
0.7 \pm 0.2 \\
\text { FN BMD }\left(\mathrm{g} / \mathrm{cm}^{2}\right) \\
0.7 \pm 0.1\end{array}$ & $\begin{array}{l}\text { Mean } \pm \text { SD: } \\
\text { WB BMD }\left(\mathrm{g} / \mathrm{cm}^{2}\right) \\
1.1 \pm 0.1 \\
\text { LS BMD }\left(\mathrm{g} / \mathrm{cm}^{2}\right) \\
1.0 \pm 0.1 \\
\text { FN BMD }\left(\mathrm{g} / \mathrm{cm}^{2}\right): \\
0.9 \pm 0.6\end{array}$ \\
\hline $\begin{array}{l}\text { Fuchs et al. } \\
\text { (2001) }\end{array}$ & USA & $\begin{array}{l}\text { A 7-mo } \\
\text { follow-up }\end{array}$ & $7.6 \pm 0.2$ & $\begin{array}{l}44(59.09 \%) \\
26 \text { chicos y } \\
18 \text { chicas }\end{array}$ & NR & $126.8 \pm 1.2$ & NR & $\begin{array}{l}\text { Healthy school } \\
\text { children }\end{array}$ & $\begin{array}{l}\text { Hologic } \\
\text { QDR/4500-A } \\
\text { dual-energy x- } \\
\text { ray } \\
\text { absorptiometry } \\
\text { scanner } \\
\end{array}$ & $\begin{array}{l}\text { Mean } \pm \text { SEM: } \\
\text { LS BMD }\left(\mathrm{g} / \mathrm{cm}^{2}\right): \\
0.550 \pm 0.008 \\
\text { FN BMD }\left(\mathrm{g} / \mathrm{cm}^{2}\right) \\
0.613 \pm 0.010\end{array}$ & $\begin{array}{l}\text { Mean } \pm \text { SEM: } \\
\text { LS BMD }\left(\mathrm{g} / \mathrm{cm}^{2}\right): \\
0.571 \pm 0.008 \\
\text { FN BMD }\left(\mathrm{g} / \mathrm{cm}^{2}\right) \\
0.635 \pm 0.009\end{array}$ \\
\hline
\end{tabular}




\begin{tabular}{|c|c|c|c|c|c|c|c|c|c|c|c|}
\hline $\begin{array}{l}\text { Gómez- } \\
\text { Brutón et al. } \\
(2017)\end{array}$ & Spain & $\begin{array}{l}\text { An 8-mo } \\
\text { follow-up }\end{array}$ & $14.1 \pm 2.3$ & $\begin{array}{l}28(57.14 \%) \\
16 \text { chicos y } \\
12 \text { chicas }\end{array}$ & $20.4 \pm 3.3$ & $159.8 \pm 11.7$ & $52.8 \pm 13.4$ & $\begin{array}{l}\text { Healthy } \\
\text { Caucasian } \\
\text { adolescents }\end{array}$ & $\begin{array}{l}\text { QDR 4500- } \\
\text { Explorer dual- } \\
\text { energy x-ray } \\
\text { absorptiometry } \\
\text { scanner }\end{array}$ & $\begin{array}{l}\text { Mean } \pm \text { SD: } \\
\text { WB BMD }\left(\mathrm{g} / \mathrm{cm}^{2}\right): \\
(\text { less head }) \\
0.889 \pm 0.076 \\
\text { LS BMD }\left(\mathrm{g} / \mathrm{cm}^{2}\right) \\
0.861 \pm 0.128 \\
\text { FN BMD }\left(\mathrm{g} / \mathrm{cm}^{2}\right) \text { : } \\
0.833 \pm 0.116 \\
\end{array}$ & $\begin{array}{l}\text { Mean } \pm \text { SD: } \\
\text { WB BMD }\left(\mathrm{g} / \mathrm{cm}^{2}\right): \\
(\text { less head }) \\
0.905 \pm 0.075 \\
\text { LS BMD }\left(\mathrm{g} / \mathrm{cm}^{2}\right) \\
0.886 \pm 0.122 \\
\text { FN BMD }\left(\mathrm{g} / \mathrm{cm}^{2}\right): \\
0.844 \pm 0.110\end{array}$ \\
\hline $\begin{array}{l}\text { Lambert et al. } \\
(2008)\end{array}$ & $\begin{array}{l}\text { United } \\
\text { Kingdom }\end{array}$ & $\begin{array}{l}\text { an } 18-\text {-mo } \\
\text { randomize } \\
\text { d } \\
\text { controlled } \\
\text { trial with } \\
2-y \\
\text { follow-up } \\
\end{array}$ & $11.4 \pm 0.5$ & $44(0 \%)$ & $19.0 \pm 3.1$ & $149.8 \pm 8.2$ & $43.2 \pm 10.1$ & $\begin{array}{l}\text { Healthy white } \\
\text { girls }\end{array}$ & $\begin{array}{l}\text { QDR 4500A } \\
\text { dual-energy x- } \\
\text { ray } \\
\text { absorptiometry } \\
\text { scanner }\end{array}$ & $\begin{array}{l}\text { Mean } \pm \text { SD: } \\
\text { WB BMD }\left(\mathrm{g} / \mathrm{cm}^{2}\right) \\
0.88 \pm 0.06 \\
\text { LS BMD }\left(\mathrm{g} / \mathrm{cm}^{2}\right) \\
0.70 \pm 0.11\end{array}$ & $\begin{array}{l}\text { Mean } \pm \text { SD: } \\
\text { WB BMD }\left(\mathrm{g} / \mathrm{cm}^{2}\right) \\
0.954 \pm 0.004 \\
\text { LS BMD }\left(\mathrm{g} / \mathrm{cm}^{2}\right) \\
0.831 \pm 0.007\end{array}$ \\
\hline $\begin{array}{l}\text { Mackelvie et } \\
\text { al. (2002) }\end{array}$ & Canada & $\begin{array}{l}\text { A 7- } \\
\text { Month } \\
\text { Randomiz } \\
\text { ed } \\
\text { Controlle } \\
\text { d }\end{array}$ & $10.3 \pm 0.7$ & $60(100 \%)$ & $18.0 \pm 4.0$ & $141.8 \pm 7.1$ & $36.6 \pm 10.1$ & $\begin{array}{l}\text { Healthy Asian } \\
\text { and white } \\
\text { children (North } \\
\text { American or } \\
\text { European } \\
\text { origin) }\end{array}$ & $\begin{array}{l}\text { QDR 4500W } \\
\text { dual-energy x- } \\
\text { ray } \\
\text { absorptiometry } \\
\text { scanner }\end{array}$ & $\begin{array}{l}\frac{\text { Changes (mean }}{ \pm 95 \% \mathrm{CI}):} \\
\underline{\mathrm{LS} \text { BMD }\left(\mathrm{g} / \mathrm{cm}^{2}\right)} \text { : } \\
0.020(0.015- \\
0.025) \\
\text { FN BMD }\left(\mathrm{g} / \mathrm{cm}^{2}\right): \\
0.014(0.009- \\
0.019) \\
\end{array}$ & \\
\hline $\begin{array}{l}\text { Markovic et } \\
\text { al. (2005) }\end{array}$ & USA & $\begin{array}{l}\text { 4-y } \\
\text { follow-up }\end{array}$ & $10.8 \pm 0.7$ & $123(0 \%)$ & NR & $145.2 \pm 7.0$ & $40.2 \pm 9.0$ & $\begin{array}{l}\text { Healthy } \\
\text { Caucasian girls }\end{array}$ & $\begin{array}{l}\text { GE-Lunar DPX- } \\
\text { L dual-energy x- } \\
\text { ray } \\
\text { absorptiometry } \\
\text { scanner } \\
\end{array}$ & $\begin{array}{l}\text { Changes }(\text { mean } \pm \\
\text { SD): } \\
\text { WB BMD }\left(\mathrm{g} / \mathrm{cm}^{2}\right) \text { : } \\
0.204 \pm 0.035\end{array}$ & \\
\hline $\begin{array}{l}\text { Markovic et } \\
\text { al. (2005) } \\
\text { Mismo } \\
\text { estudio que el } \\
\text { anterior }\end{array}$ & USA & $\begin{array}{l}\text { 7-y folow- } \\
\text { up }\end{array}$ & $10.8 \pm 0.7$ & $100(0 \%)$ & NR & $145.2 \pm 7.0$ & $40.2 \pm 9.0$ & $\begin{array}{l}\text { Healthy } \\
\text { Caucasian girls }\end{array}$ & $\begin{array}{l}\text { GE-Lunar DPX- } \\
\text { L dual-energy x- } \\
\text { ray } \\
\text { absorptiometry } \\
\text { scanner } \\
\end{array}$ & $\begin{array}{l}\text { Changes }(\text { mean } \pm \\
\text { SD): } \\
\text { WB BMD }\left(\mathrm{g} / \mathrm{cm}^{2}\right) \text { : } \\
0.263 \pm 0.044\end{array}$ & \\
\hline $\begin{array}{l}\text { Nickols et al. } \\
\text { (1999) }\end{array}$ & USA & $\begin{array}{l}\text { 6-month } \\
\text { follow-up }\end{array}$ & $10.1 \pm 0.3$ & $9(0 \%)$ & NR & $138.9 \pm 2.4$ & $30.3 \pm 1.7$ & $\begin{array}{l}\text { Healthy } \\
\text { premenarcheal } \\
\text { girls }\end{array}$ & $\begin{array}{l}\text { QDR-1000 W } \\
\text { dual-energy x- } \\
\text { ray }\end{array}$ & $\begin{array}{l}\text { Mean } \pm \text { SEM: } \\
\text { WB BMD }\left(\mathrm{g} / \mathrm{cm}^{2}\right) \\
0.835 \pm 0.012\end{array}$ & $\begin{array}{l}\text { Mean } \pm \text { SEM: } \\
\text { WB BMD }\left(\mathrm{g} / \mathrm{cm}^{2}\right) \\
0.845 \pm 0.013\end{array}$ \\
\hline
\end{tabular}




\begin{tabular}{|c|c|c|c|c|c|c|c|c|c|c|c|}
\hline & & & & & & & & Caucasian & $\begin{array}{l}\text { absorptiometry } \\
\text { scanner }\end{array}$ & $\begin{array}{l}\text { LS BMD }\left(\mathrm{g} / \mathrm{cm}^{2}\right) \\
0.620 \pm 0.019 \\
\text { FN BMD }\left(\mathrm{g} / \mathrm{cm}^{2}\right) \\
0.647 \pm 0.023\end{array}$ & $\begin{array}{l}\text { LS BMD }\left(\mathrm{g} / \mathrm{cm}^{2}\right) \\
0.6412 \pm 0.020 \\
\text { FN BMD }\left(\mathrm{g} / \mathrm{cm}^{2}\right) \\
0.663 \pm 0.024\end{array}$ \\
\hline $\begin{array}{l}\text { Nickols et al. } \\
\text { (1999) } \\
\text { Mismo } \\
\text { estudio que el } \\
\text { anterior }\end{array}$ & USA & $\begin{array}{l}\text { 12-month } \\
\text { follow-up }\end{array}$ & $10.1 \pm 0.3$ & $9(0 \%)$ & NR & $138.9 \pm 2.4$ & $30.3 \pm 1.7$ & $\begin{array}{l}\text { Healthy } \\
\text { premenarcheal } \\
\text { girls } \\
\text { Caucasian }\end{array}$ & $\begin{array}{l}\text { QDR-1000 W } \\
\text { dual-energy x- } \\
\text { ray } \\
\text { absorptiometry } \\
\text { scanner }\end{array}$ & $\begin{array}{l}\text { Mean } \pm \text { SEM: } \\
\text { WB BMD }\left(\mathrm{g} / \mathrm{cm}^{2}\right) \\
0.835 \pm 0.012 \\
\text { LS BMD }\left(\mathrm{g} / \mathrm{cm}^{2}\right) \\
0.6200 \pm 0.019 \\
\text { FN BMD }\left(\mathrm{g} / \mathrm{cm}^{2}\right) \\
0.647 \pm 0.023\end{array}$ & $\begin{array}{l}\text { Mean } \pm \text { SEM: } \\
\text { WB BMD }\left(\mathrm{g} / \mathrm{cm}^{2}\right) \\
0.864 \pm 0.014 \\
\text { LS BMD }\left(\mathrm{g} / \mathrm{cm}^{2}\right) \\
0.666 \pm 0.022 \\
\text { FN BMD }\left(\mathrm{g} / \mathrm{cm}^{2}\right) \\
0.675 \pm 0.025\end{array}$ \\
\hline $\begin{array}{l}\text { Vaitkeviciute } \\
\text { et al. (2016) }\end{array}$ & Estonia & $\begin{array}{l}\text { 12-month } \\
\text { follow-up }\end{array}$ & $11.9 \pm 0.6$ & $96(100 \%)$ & $20.5 \pm 5.2$ & $153.8 \pm 7.4$ & $49.3 \pm 16.0$ & $\begin{array}{l}\text { Healthy school } \\
\text { children }\end{array}$ & $\begin{array}{l}\text { Lunar DPX-IQ } \\
\text { dual-energy x- } \\
\text { ray } \\
\text { absorptiometry } \\
\text { scanner }\end{array}$ & $\begin{array}{l}\text { Mean } \pm \text { SD: } \\
\text { WB BMD }\left(\mathrm{g} / \mathrm{cm}^{2}\right) \\
0.983 \pm 0.069 \\
\text { LS BMD }\left(\mathrm{g} / \mathrm{cm}^{2}\right) \\
0.831 \pm 0.097 \\
\text { FN BMD }\left(\mathrm{g} / \mathrm{cm}^{2}\right) \\
0.895 \pm 0.086\end{array}$ & $\begin{array}{l}\text { Mean } \pm \text { SD: } \\
\text { WB BMD }\left(\mathrm{g} / \mathrm{cm}^{2}\right) \\
1.018 \pm 0.081 \\
\text { LS BMD }\left(\mathrm{g} / \mathrm{cm}^{2}\right) \\
0.890 \pm 0.121 \\
\text { FN BMD }\left(\mathrm{g} / \mathrm{cm}^{2}\right) \\
0.940 \pm 0.103\end{array}$ \\
\hline $\begin{array}{l}\text { Vaitkeviciute } \\
\text { et al. (2016) } \\
\text { Mismo } \\
\text { estudio que el } \\
\text { anterior }\end{array}$ & Estonia & $\begin{array}{l}\text { 24-month } \\
\text { follow-up }\end{array}$ & $11.9 \pm 0.6$ & $96(100 \%)$ & $20.5 \pm 5.2$ & $153.8 \pm 7.4$ & $49.3 \pm 16.0$ & $\begin{array}{l}\text { Healthy school } \\
\text { children }\end{array}$ & $\begin{array}{l}\text { Lunar DPX-IQ } \\
\text { dual-energy x- } \\
\text { ray } \\
\text { absorptiometry } \\
\text { scanner }\end{array}$ & $\begin{array}{l}\text { Mean } \pm \text { SD: } \\
\text { WB BMD }\left(\mathrm{g} / \mathrm{cm}^{2}\right) \\
0.983 \pm 0.069 \\
\text { LS BMD }\left(\mathrm{g} / \mathrm{cm}^{2}\right) \\
0.831 \pm 0.097 \\
\text { FN BMD }\left(\mathrm{g} / \mathrm{cm}^{2}\right) \\
0.895 \pm 0.086\end{array}$ & $\begin{array}{l}\text { Mean } \pm \text { SD: } \\
\text { WB BMD }\left(\mathrm{g} / \mathrm{cm}^{2}\right) \\
1.018 \pm 0.081 \\
\text { LS BMD }\left(\mathrm{g} / \mathrm{cm}^{2}\right) \\
0.890 \pm 0.121 \\
\text { FN BMD }\left(\mathrm{g} / \mathrm{cm}^{2}\right) \\
0.940 \pm 0.103\end{array}$ \\
\hline $\begin{array}{l}\text { Zouch et al. } \\
\text { (2015) }\end{array}$ & France & $\begin{array}{l}\text { A 3-Yr } \\
\text { Longitudi } \\
\text { nal Study }\end{array}$ & $11.74 \pm 0.64$ & $23(100 \%)$ & $18.6 \pm 2.9$ & $152.0 \pm 6.0$ & $42.6 \pm 8.3$ & $\begin{array}{l}\text { Healthy } \\
\text { Caucasian } \\
\text { boys }\end{array}$ & $\begin{array}{l}\text { Hologic } \\
\text { WB Delphi } \\
\text { dual-energy x- } \\
\text { ray } \\
\text { absorptiometry } \\
\text { scanner }\end{array}$ & $\begin{array}{l}\text { Mean } \pm \text { SD: } \\
\text { WB BMD }\left(\mathrm{g} / \mathrm{cm}^{2}\right) \\
0.902 \pm 0.042 \\
\text { LS BMD }\left(\mathrm{g} / \mathrm{cm}^{2}\right) \\
0.679 \pm 0.071 \\
\text { FN BMD }\left(\mathrm{g} / \mathrm{cm}^{2}\right) \\
0.753 \pm 0.065\end{array}$ & $\begin{array}{l}\text { Mean } \pm \text { SD: } \\
\text { WB BMD }\left(\mathrm{g} / \mathrm{cm}^{2}\right) \\
1.010 \pm 0.087 \\
\text { LS BMD }\left(\mathrm{g} / \mathrm{cm}^{2}\right) \\
0.843 \pm 0.121 \\
\text { FN BMD }\left(\mathrm{g} / \mathrm{cm}^{2}\right) \\
0.840 \pm 0.100\end{array}$ \\
\hline $\begin{array}{l}\text { Bradney et al. } \\
\text { (1998) }\end{array}$ & $\begin{array}{l}\text { Australia/ } \\
\text { USA }\end{array}$ & $\begin{array}{l}\text { 8-month } \\
\text { follow-up }\end{array}$ & $10.3 \pm 0.2$ & $19(100 \%)$ & NR & $142.2 \pm 1.3$ & $40.1 \pm 1.6$ & $\begin{array}{l}\text { Healthy school } \\
\text { children }\end{array}$ & $\begin{array}{l}\text { Lunar DPX-L } \\
\text { dual-energy x- } \\
\text { ray }\end{array}$ & $\begin{array}{l}\text { Mean } \pm \text { SEM: } \\
\text { WB BMD }\left(\mathrm{g} / \mathrm{cm}^{2}\right) \\
0.92 \pm 0.01 \\
\text { LS BMD }\left(\mathrm{g} / \mathrm{cm}^{2}\right)\end{array}$ & $\begin{array}{l}\frac{\text { Changes per month }}{(\text { mean } \pm \text { SEM }):} \\
\text { WB BMD }\left(\mathrm{g} / \mathrm{cm}^{2}\right): \\
0.002 \pm 0.001\end{array}$ \\
\hline
\end{tabular}




\begin{tabular}{|c|c|c|c|c|c|c|c|c|c|c|c|}
\hline & & & & & & & & & $\begin{array}{l}\text { absorptiometry } \\
\text { scanner }\end{array}$ & $0.77 \pm 0.02$ & $\begin{array}{l}\text { LS BMD }\left(\mathrm{g} / \mathrm{cm}^{2}\right) \\
0.002 \pm 0.001\end{array}$ \\
\hline $\begin{array}{l}\text { Johannsen et } \\
\text { al. (2003) }\end{array}$ & USA & \begin{tabular}{|l|}
12 -week \\
interventi \\
on \\
randomize \\
d trial
\end{tabular} & $10.0 \pm 5.1$ & $26(45.2 \%)$ & NR & $136.6 \pm 30.7$ & $39.3 \pm 20.7$ & $\begin{array}{l}\text { Healthy } \\
\text { children }\end{array}$ & $\begin{array}{l}\text { Hologic 4500A } \\
\text { dual-energy x- } \\
\text { ray } \\
\text { absorptiometry } \\
\text { scanner }\end{array}$ & $\begin{array}{l}\text { Changes }(\text { mean } \pm \\
\text { SEM): } \\
\text { LS BMD }\left(\mathrm{g} / \mathrm{cm}^{2}\right) \\
0.009 \pm 0.004 \\
\text { FN BMD }\left(\mathrm{g} / \mathrm{cm}^{2}\right) \\
0.001 \pm 0.005\end{array}$ & \\
\hline $\begin{array}{l}\text { Laing et al. } \\
\text { (2005) }\end{array}$ & USA & \begin{tabular}{|l|} 
A 24- \\
month \\
quasi- \\
experimen \\
tal
\end{tabular} & $6.0 \pm 1.49$ & $78(0 \%)$ & $17.3 \pm 2.88$ & $119.0 \pm 11.8$ & $25.2 \pm 7.6$ & $\begin{array}{l}\text { Healthy } \\
\text { females }\end{array}$ & $\begin{array}{l}\text { Hologic QDR- } \\
\text { 1000W dual- } \\
\text { energy x-ray } \\
\text { absorptiometry } \\
\text { scanner }\end{array}$ & $\begin{array}{l}\text { Mean } \pm \text { SD: } \\
\text { WB BMD }\left(\mathrm{g} / \mathrm{cm}^{2}\right) \\
0.669 \pm 0.06 \\
\text { LS BMD }\left(\mathrm{g} / \mathrm{cm}^{2}\right) \\
0.557 \pm 0.07\end{array}$ & $\begin{array}{l}\text { Mean } \pm \text { SD: } \\
\text { WB BMD }\left(\mathrm{g} / \mathrm{cm}^{2}\right) \\
0.736 \pm 0.07 \\
\text { LS BMD }\left(\mathrm{g} / \mathrm{cm}^{2}\right) \\
0.609 \pm 0.08\end{array}$ \\
\hline $\begin{array}{l}\text { Linden et al. } \\
(2006)\end{array}$ & Sweden & $\begin{array}{l}\text { 2-year } \\
\text { prospectiv } \\
\text { e } \\
\text { controlled } \\
\text { exercise } \\
\text { interventi } \\
\text { on trial }\end{array}$ & $7.9 \pm 0.6$ & $50(0 \%)$ & NR & $129.1 \pm 7.9$ & $27.4 \pm 5.5$ & $\begin{array}{l}\text { Healthy } \\
\text { elementary } \\
\text { schools in a } \\
\text { middle-class } \\
\text { area }\end{array}$ & $\begin{array}{l}\text { Lunar DPX-L } \\
\text { dual-energy x- } \\
\text { ray } \\
\text { absorptiometry } \\
\text { scanner }\end{array}$ & $\begin{array}{l}\text { Mean } \pm \text { SD: } \\
\text { WB BMD }\left(\mathrm{g} / \mathrm{cm}^{2}\right) \\
0.84 \pm 0.05 \\
\text { LS BMD }\left(\mathrm{g} / \mathrm{cm}^{2}\right) \\
0.70 \pm 0.08 \\
\text { FN BMD }\left(\mathrm{g} / \mathrm{cm}^{2}\right) \\
0.71 \pm 0.10\end{array}$ & $\begin{array}{l}\frac{\text { Changes per year }}{(\text { mean } \pm \text { SD }):} \\
\text { WB BMD }\left(\mathrm{g} / \mathrm{cm}^{2}\right) \\
0.024 \pm 0.009 \\
\text { LS BMD }\left(\mathrm{g} / \mathrm{cm}^{2}\right) \\
0.026 \pm 0.015 \\
\text { FN BMD }\left(\mathrm{g} / \mathrm{cm}^{2}\right) \\
0.040 \pm 0.040\end{array}$ \\
\hline $\begin{array}{l}\text { MacKelvie et } \\
\text { al.(2001) }\end{array}$ & Canada & $\begin{array}{l}\text { 7-month } \\
\text { randomize } \\
\text { d, } \\
\text { prospectiv } \\
\text { e, school- } \\
\text { based } \\
\text { interventi } \\
\text { on }\end{array}$ & $\begin{array}{l}\text { Prepubertal: } \\
10.1 \pm 0.5 \\
\text { Early } \\
\text { pubertal: } \\
10.5 \pm 0.6\end{array}$ & $\begin{array}{l}\text { Prepubertal: } \\
26(0 \%) \\
\text { Early } \\
\text { pubertal: } \\
64(0 \%)\end{array}$ & NR & $\begin{array}{l}\text { Prepubertal: } \\
137.3 \pm 6.2 \\
\text { Early } \\
\text { pubertal: } \\
145.6 \pm 6.4\end{array}$ & $\begin{array}{l}\text { Prepubertal: } \\
31.1 \pm 5.6 \\
\text { Early } \\
\text { pubertal: } \\
41.3 \pm 8.3\end{array}$ & $\begin{array}{l}\text { Healthy Asian } \\
\text { and white } \\
\text { children (North } \\
\text { American or } \\
\text { European } \\
\text { origin) }\end{array}$ & $\begin{array}{l}\text { Hologic QDR } \\
4500 \mathrm{~W} \text { dual- } \\
\text { energy x-ray } \\
\text { absorptiometry } \\
\text { scanner }\end{array}$ & $\begin{array}{l}\frac{\text { Prepubertal }(\text { mean }}{ \pm \text { SD): }} \\
\underline{\text { WB BMD }\left(\mathrm{g} / \mathrm{cm}^{2}\right):} \\
0.860 \pm 0.040 \\
\mathrm{LS} \mathrm{BMD}\left(\mathrm{g} / \mathrm{cm}^{2}\right): \\
0.630 \pm 0.060 \\
\text { FN BMD }\left(\mathrm{g} / \mathrm{cm}^{2}\right): \\
0.630 \pm 0.070 \\
\text { Early pubertal } \\
\underline{(\text { mean } \pm \text { SD }):} \\
\text { WB BMD }\left(\mathrm{g} / \mathrm{cm}^{2}\right):\end{array}$ & $\begin{array}{l}\text { Prepubertal } \\
\text { changes }(\text { mean } \pm \\
95 \% \mathrm{CI}): \\
\text { WB BMD }\left(\mathrm{g} / \mathrm{cm}^{2}\right): \\
0.017(0.011- \\
0.023) \\
\text { LS BMD }\left(\mathrm{g} / \mathrm{cm}^{2}\right): \\
0.027(0.019- \\
0.034) \\
\text { FN BMD }\left(\mathrm{g} / \mathrm{cm}^{2}\right): \\
0.024(0.016- \\
0.031)\end{array}$ \\
\hline
\end{tabular}




\begin{tabular}{|c|c|c|c|c|c|c|c|c|c|c|c|}
\hline & & & & & & & & & & $\begin{array}{l}0.870 \pm 0.070 \\
\mathrm{LS} B M D\left(\mathrm{~g} / \mathrm{cm}^{2}\right): \\
0.690 \pm 0.100 \\
\text { FN BMD }\left(\mathrm{g} / \mathrm{cm}^{2}\right) \\
0.670 \pm 0.090\end{array}$ & $\begin{array}{l}\frac{\text { Early pubertal }}{(\text { mean } \pm \text { SD }):} \\
\text { WB BMD }\left(\mathrm{g} / \mathrm{cm}^{2}\right): \\
0.030(0.025- \\
0.035) \\
\text { LS BMD }\left(\mathrm{g} / \mathrm{cm}^{2}\right): \\
0.044(0.038- \\
0.049) \\
\text { FN BMD }\left(\mathrm{g} / \mathrm{cm}^{2}\right): \\
0.034(0.028- \\
0.039)\end{array}$ \\
\hline $\begin{array}{l}\text { McKay et al. } \\
(2000)\end{array}$ & Canada & $\begin{array}{l}\text { A } 8 \\
\text { months } \\
\text { randomize } \\
\text { d school- } \\
\text { based } \\
\text { exercise } \\
\text { interventi } \\
\text { on study }\end{array}$ & $\begin{array}{l}6.9 \text { to } \\
10.2 \text { years }\end{array}$ & 81 (NR) & NR & $133.9 \pm 0.7$ & $30.5 \pm 0.8$ & $\begin{array}{l}\text { Healthy Asian } \\
\text { and white } \\
\text { children (North } \\
\text { American or } \\
\text { European } \\
\text { origin) }\end{array}$ & $\begin{array}{l}\text { Hologic QDR } \\
4500 \mathrm{~W} \text { dual- } \\
\text { energy X-ray } \\
\text { absorptiometry } \\
\text { scanner }\end{array}$ & $\begin{array}{l}\text { Mean } \pm \text { SEM: } \\
\text { WB BMD }\left(\mathrm{g} / \mathrm{cm}^{2}\right) \\
0.807 \pm 0.006 \\
\text { LS BMD }\left(\mathrm{g} / \mathrm{cm}^{2}\right) \\
0.581 \pm 0.007 \\
\text { FN BMD }\left(\mathrm{g} / \mathrm{cm}^{2}\right) \\
0.642 \pm 0.008\end{array}$ & $\begin{array}{l}\text { Mean } \pm \text { SEM: } \\
\text { WB BMD }\left(\mathrm{g} / \mathrm{cm}^{2}\right): \\
0.818 \pm 0.006 \\
\text { LS BMD }\left(\mathrm{g} / \mathrm{cm}^{2}\right): \\
0.592 \pm 0.007 \\
\text { FN BMD }\left(\mathrm{g} / \mathrm{cm}^{2}\right) \\
0.661 \pm 0.009\end{array}$ \\
\hline $\begin{array}{l}\text { Moriss et al. } \\
\text { (1997) }\end{array}$ & Australia & $\begin{array}{l}\text { Prospectiv } \\
\text { e Ten- } \\
\text { Month } \\
\text { Exercise } \\
\text { Interventi } \\
\text { on }\end{array}$ & $9.5 \pm 0.9$ & $38(0 \%)$ & NR & $138.6 \pm 6.4$ & $34.8 \pm 5.2$ & $\begin{array}{l}\text { Healthy school } \\
\text { girls }\end{array}$ & $\begin{array}{l}\text { Hologic QDR- } \\
2000+\text { dual- } \\
\text { energy x-ray } \\
\text { absorptiometry } \\
\text { scanner }\end{array}$ & $\begin{array}{l}\text { Mean } \pm \text { SEM: } \\
\text { WB BMD }\left(\mathrm{g} / \mathrm{cm}^{2}\right): \\
0.810 \pm 0.01 \\
\text { LS BMD }\left(\mathrm{g} / \mathrm{cm}^{2}\right) \\
0.637 \pm 0.01 \\
\text { FN BMD }\left(\mathrm{g} / \mathrm{cm}^{2}\right): \\
0.690 \pm 0.07\end{array}$ & $\begin{array}{l}\text { Changes (mean } \pm \\
\text { SEM): } \\
\text { WB BMD }\left(\mathrm{g} / \mathrm{cm}^{2}\right) \\
0.010 \pm 0.01 \\
\text { LS BMD }\left(\mathrm{g} / \mathrm{cm}^{2}\right) \\
0.008 \pm 0.05 \\
\text { FN BMD }\left(\mathrm{g} / \mathrm{cm}^{2}\right): \\
0.012 \pm 0.03\end{array}$ \\
\hline $\begin{array}{l}\text { Nichols et al. } \\
(2001)\end{array}$ & USA & $\begin{array}{l}15 \text { months } \\
\text { follow-up }\end{array}$ & $15.7 \pm 0.1$ & $11(0 \%)$ & NR & $158.2 \pm 3.1$ & $63.8 \pm 5.2$ & $\begin{array}{l}\text { Healthy } \\
\text { females }\end{array}$ & $\begin{array}{l}\text { Lunar DPX dual- } \\
\text { energy X-ray } \\
\text { absorptiometry } \\
\text { scanner }\end{array}$ & $\begin{array}{l}\text { Mean } \pm \text { SD: } \\
\text { WB BMD }\left(\mathrm{g} / \mathrm{cm}^{2}\right): \\
1.111 \pm 0.066 \\
\text { LS BMD }\left(\mathrm{g} / \mathrm{cm}^{2}\right): \\
1.158 \pm 0.135 \\
\text { FN BMD }\left(\mathrm{g} / \mathrm{cm}^{2}\right):\end{array}$ & $\begin{array}{l}\text { Mean } \pm \text { SD: } \\
\text { WB BMD }\left(\mathrm{g} / \mathrm{cm}^{2}\right): \\
1.129 \pm 0.065 \\
\text { LS BMD }\left(\mathrm{g} / \mathrm{cm}^{2}\right) \\
1.190 \pm 0.125 \\
\text { FN BMD }\left(\mathrm{g} / \mathrm{cm}^{2}\right):\end{array}$ \\
\hline
\end{tabular}




\begin{tabular}{|c|c|c|c|c|c|c|c|c|c|c|c|}
\hline & & & & & & & & & & $1.034 \pm 0.086$ & $1.048 \pm 0.075$ \\
\hline $\begin{array}{l}\text { Van } \\
\text { Langendonck } \\
\text { et al. (2003) }\end{array}$ & Belgium & $\begin{array}{l}9 \text { months } \\
\text { follow-up }\end{array}$ & $8.7 \pm 0.7$ & $21(0 \%)$ & NR & $132.22 \pm 6.37$ & $28.8 \pm 4.5$ & $\begin{array}{l}\text { Healthy female } \\
\text { twins }\end{array}$ & $\begin{array}{l}\text { Hologic QDR- } \\
\text { 4500A dual- } \\
\text { energy x-ray } \\
\text { absorptiometry } \\
\text { scanner }\end{array}$ & $\begin{array}{l}\text { Mean } \pm \text { SD: } \\
\text { WB BMD }\left(\mathrm{g} / \mathrm{cm}^{2}\right) \\
0.850 \pm 0.030 \\
\text { LS BMD }\left(\mathrm{g} / \mathrm{cm}^{2}\right): \\
0.850 \pm 0.030 \\
\text { FN BMD }\left(\mathrm{g} / \mathrm{cm}^{2}\right) \\
0.630 \pm 0.060\end{array}$ & $\begin{array}{l}\text { Changes (mean } \pm \\
\text { SD): } \\
\text { WB BMD }\left(\mathrm{g} / \mathrm{cm}^{2}\right): \\
0.020 \pm 0.020 \\
\text { LS BMD }\left(\mathrm{g} / \mathrm{cm}^{2}\right): \\
0.010 \pm 0.020 \\
\text { FN BMD }\left(\mathrm{g} / \mathrm{cm}^{2}\right): \\
0.020 \pm 0.020\end{array}$ \\
\hline $\begin{array}{l}\text { Chevalley et } \\
\text { al. (2011) }\end{array}$ & Switzerland & $\begin{array}{l}\text { an 8-yr } \\
\text { cohort } \\
\text { study }\end{array}$ & $7.4 \pm 0.4$ & $89(100 \%)$ & $15.9 \pm 2.0$ & $125.5 \pm 6.2$ & $25.2 \pm 5.0$ & $\begin{array}{l}\text { Healthy } \\
\text { prepubertal } \\
\text { Caucasian boys }\end{array}$ & $\begin{array}{l}\text { Hologic QDR } \\
4500 \text { dual-energy } \\
\text { X-ray } \\
\text { absorptiometry } \\
\text { scanner }\end{array}$ & $\begin{array}{l}\text { Mean } \pm \text { SD: } \\
\text { LS BMD }\left(\mathrm{g} / \mathrm{cm}^{2}\right) \\
0.568 \pm 0.052 \\
\text { FN BMD }\left(\mathrm{g} / \mathrm{cm}^{2}\right) \\
0.688 \pm 0.070\end{array}$ & $\begin{array}{l}\text { Mean } \pm \text { SD: } \\
\text { LS BMD }\left(\mathrm{g} / \mathrm{cm}^{2}\right) \\
0.918 \pm 0.135 \\
\text { FN BMD }\left(\mathrm{g} / \mathrm{cm}^{2}\right) \\
0.901 \pm 0.133\end{array}$ \\
\hline $\begin{array}{l}\text { Gustavsson et } \\
\text { al. (2003) }\end{array}$ & Sweden & $\begin{array}{l}3 \text { years } \\
\text { follow-up }\end{array}$ & $16.1 \pm 0.6$ & $24(100 \%)$ & NR & $179.0 \pm 6.0$ & $69.2 \pm 10.1$ & $\begin{array}{l}\text { Healthy } \\
\text { Caucasian boys }\end{array}$ & $\begin{array}{l}\text { Lunar DPX-L } \\
\text { dual-energy x- } \\
\text { ray } \\
\text { absorptiometry } \\
\text { scanner }\end{array}$ & $\begin{array}{l}\text { Mean } \pm \text { SD: } \\
\text { WB BMD }\left(\mathrm{g} / \mathrm{cm}^{2}\right): \\
1.15 \pm 0.11 \\
\text { LS BMD }\left(\mathrm{g} / \mathrm{cm}^{2}\right) \\
1.10 \pm 0.14 \\
\text { FN BMD }\left(\mathrm{g} / \mathrm{cm}^{2}\right) \\
1.13 \pm 0.15\end{array}$ & $\begin{array}{l}\text { Mean } \pm \text { SD: } \\
\text { WB BMD }\left(\mathrm{g} / \mathrm{cm}^{2}\right) \\
1.26 \pm 0.09 \\
\text { LS BMD }\left(\mathrm{g} / \mathrm{cm}^{2}\right) \\
1.24 \pm 0.14 \\
\text { FN BMD }\left(\mathrm{g} / \mathrm{cm}^{2}\right) \\
1.21 \pm 0.16\end{array}$ \\
\hline $\begin{array}{l}\text { Katzman et } \\
\text { al. (1991) }\end{array}$ & USA & $\begin{array}{l}2 \text { years } \\
\text { follow-up }\end{array}$ & $14.3 \pm 3.6$ & $45(0 \%)$ & $20.0 \pm 2.9$ & $158.0 \pm 13.2$ & $50.6 \pm 12.7$ & $\begin{array}{l}\text { Healthy } \\
\text { adolescent } \\
\text { females }\end{array}$ & $\begin{array}{l}\text { Hologic QDR } \\
\text { 1000W dual- } \\
\text { energy x-ray } \\
\text { absorptiometry } \\
\text { scanner } \\
\end{array}$ & $\begin{array}{l}\text { Mean } \pm \text { SD: } \\
\text { WB BMD }\left(\mathrm{g} / \mathrm{cm}^{2}\right) \\
0.904 \pm 0.130 \\
\text { LS BMD }\left(\mathrm{g} / \mathrm{cm}^{2}\right) \\
1.009 \pm 0.155\end{array}$ & $\begin{array}{l}\text { Mean } \pm \text { SD: } \\
\text { WB BMD }\left(\mathrm{g} / \mathrm{cm}^{2}\right) \\
0.993 \pm 0.114 \\
\text { LS BMD }\left(\mathrm{g} / \mathrm{cm}^{2}\right) \\
1.005 \pm 0.142\end{array}$ \\
\hline $\begin{array}{l}\text { Maggio et al. } \\
(2012)\end{array}$ & Switzerland & $\begin{array}{l}9 \text { month } \\
\text { follow-up }\end{array}$ & $10.5 \pm 3.0$ & $17(47 \%)$ & $17.8 \pm 2.9$ & $143.1 \pm 19.1$ & $38.3 \pm 15.7$ & $\begin{array}{l}\text { Healthy } \\
\text { children }\end{array}$ & $\begin{array}{l}\text { GE Lunar } \\
\text { Prodigyi dual- } \\
\text { energy x-ray } \\
\text { absorptiometry } \\
\text { scanner }\end{array}$ & $\begin{array}{l}\text { Mean } \pm \text { SD: } \\
\text { WB BMD }\left(\mathrm{g} / \mathrm{cm}^{2}\right) \\
0.94 \pm 0.13 \\
\text { LS BMD }\left(\mathrm{g} / \mathrm{cm}^{2}\right) \\
0.83 \pm 0.25 \\
\text { FN BMD }\left(\mathrm{g} / \mathrm{cm}^{2}\right) \\
0.86 \pm 0.17\end{array}$ & $\begin{array}{l}\text { Changes (mean } \pm \\
\text { SD): } \\
\text { WB BMD }\left(\mathrm{g} / \mathrm{cm}^{2}\right): \\
0.020 \pm 0.007 \\
\text { LS BMD }\left(\mathrm{g} / \mathrm{cm}^{2}\right) \\
0.033 \pm 0.014 \\
\text { FN BMD }\left(\mathrm{g} / \mathrm{cm}^{2}\right) \\
0.025 \pm 0.019\end{array}$ \\
\hline
\end{tabular}




\begin{tabular}{|c|c|c|c|c|c|c|c|c|c|c|c|}
\hline $\begin{array}{l}\text { Mølgaard et } \\
\text { al. (2010) }\end{array}$ & Denmark & $\begin{array}{l}12 \text { month } \\
\text { follow-up }\end{array}$ & $11.4 \pm 0.2$ & $74(0 \%)$ & NR & $150.1 \pm 6.9$ & $40.5 \pm 7.9$ & $\begin{array}{l}\text { Healthy Danish } \\
\text { Caucasian girls }\end{array}$ & $\begin{array}{l}\text { Hologic 1000/W } \\
\text { dual-energy x- } \\
\text { ray } \\
\text { absorptiometry } \\
\text { scanner }\end{array}$ & $\begin{array}{l}\text { Mean } \pm \text { SD: } \\
\text { WB BMD }\left(\mathrm{g} / \mathrm{cm}^{2}\right): \\
0.863 \pm 0.064 \\
\text { LS BMD }\left(\mathrm{g} / \mathrm{cm}^{2}\right) \\
0.697 \pm 0.102\end{array}$ & $\begin{array}{l}\text { Mean } \pm \text { SD: } \\
\text { WB BMD }\left(\mathrm{g} / \mathrm{cm}^{2}\right): \\
0.909 \pm 0.075 \\
\text { LS BMD }\left(\mathrm{g} / \mathrm{cm}^{2}\right): \\
0.788 \pm 0.121\end{array}$ \\
\hline $\begin{array}{l}\text { Nogueira et } \\
\text { al. (2015) }\end{array}$ & Australia & $\begin{array}{l}\text { A 9- } \\
\text { month, } \\
\text { cluster- } \\
\text { controlled } \\
\text { trial }\end{array}$ & $10.7 \pm 0.6$ & $68(100 \%)$ & NR & $143.7 \pm 6.2$ & $39.6 \pm 9.2$ & $\begin{array}{l}\text { Healthy school } \\
\text { children }\end{array}$ & $\begin{array}{l}\text { Norland Medical } \\
\text { XR800 dual- } \\
\text { energy x-ray } \\
\text { absorptiometry } \\
\text { scanner }\end{array}$ & $\begin{array}{l}\text { Mean } \pm \text { SD: } \\
\text { WB BMD }\left(\mathrm{g} / \mathrm{cm}^{2}\right): \\
0.765 \pm 0.083 \\
\text { LS BMD }\left(\mathrm{g} / \mathrm{cm}^{2}\right): \\
0.674 \pm 0.123 \\
\text { FN BMD }\left(\mathrm{g} / \mathrm{cm}^{2}\right): \\
0.803 \pm 0.116\end{array}$ & $\begin{array}{l}\text { Mean } \pm \text { SD: } \\
\text { WB BMD }\left(\mathrm{g} / \mathrm{cm}^{2}\right): \\
0.806 \pm 0.103 \\
\text { LS BMD }\left(\mathrm{g} / \mathrm{cm}^{2}\right): \\
0.705 \pm 0.150 \\
\text { FN BMD }\left(\mathrm{g} / \mathrm{cm}^{2}\right): \\
0.843 \pm 0.134\end{array}$ \\
\hline
\end{tabular}




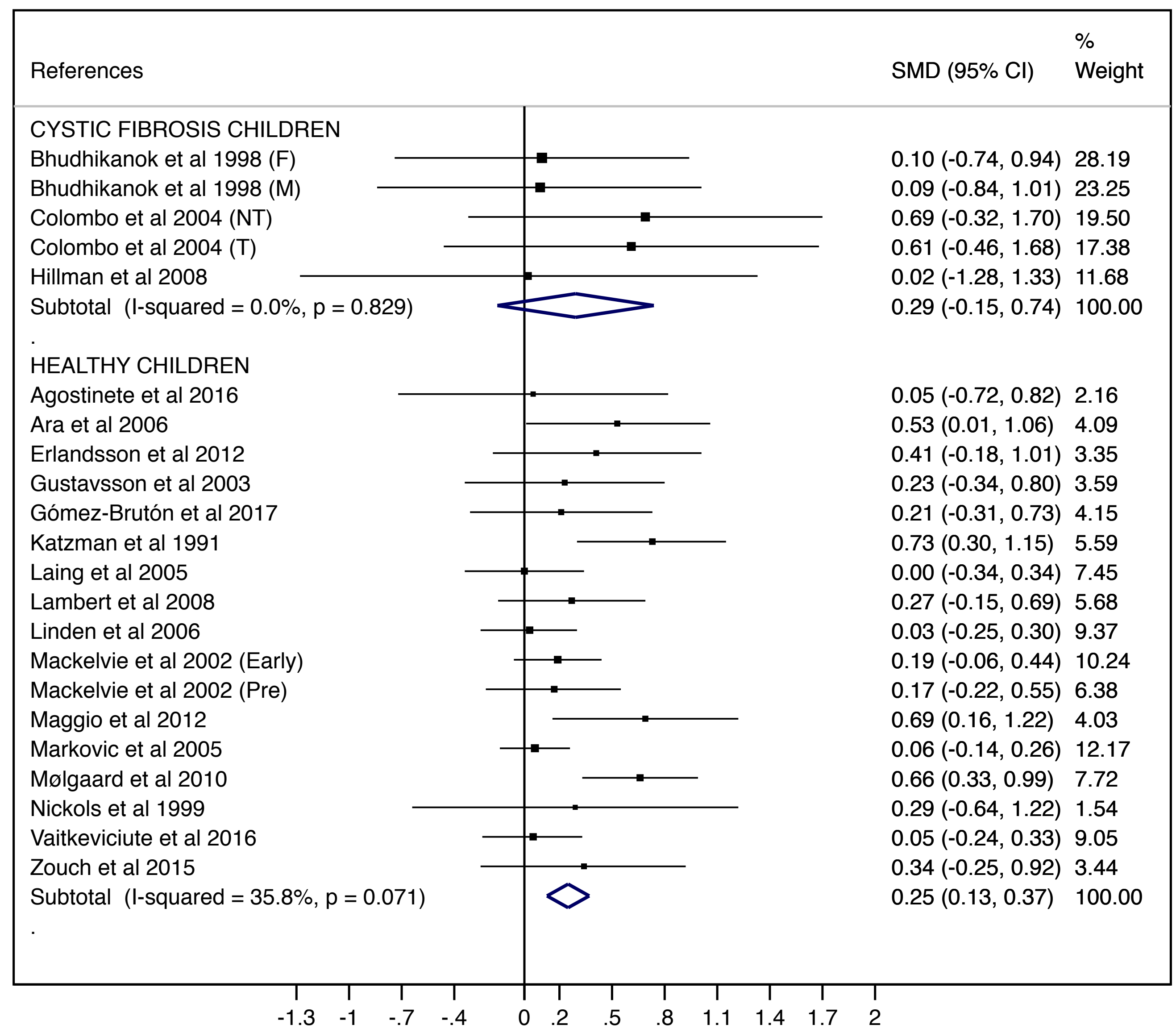




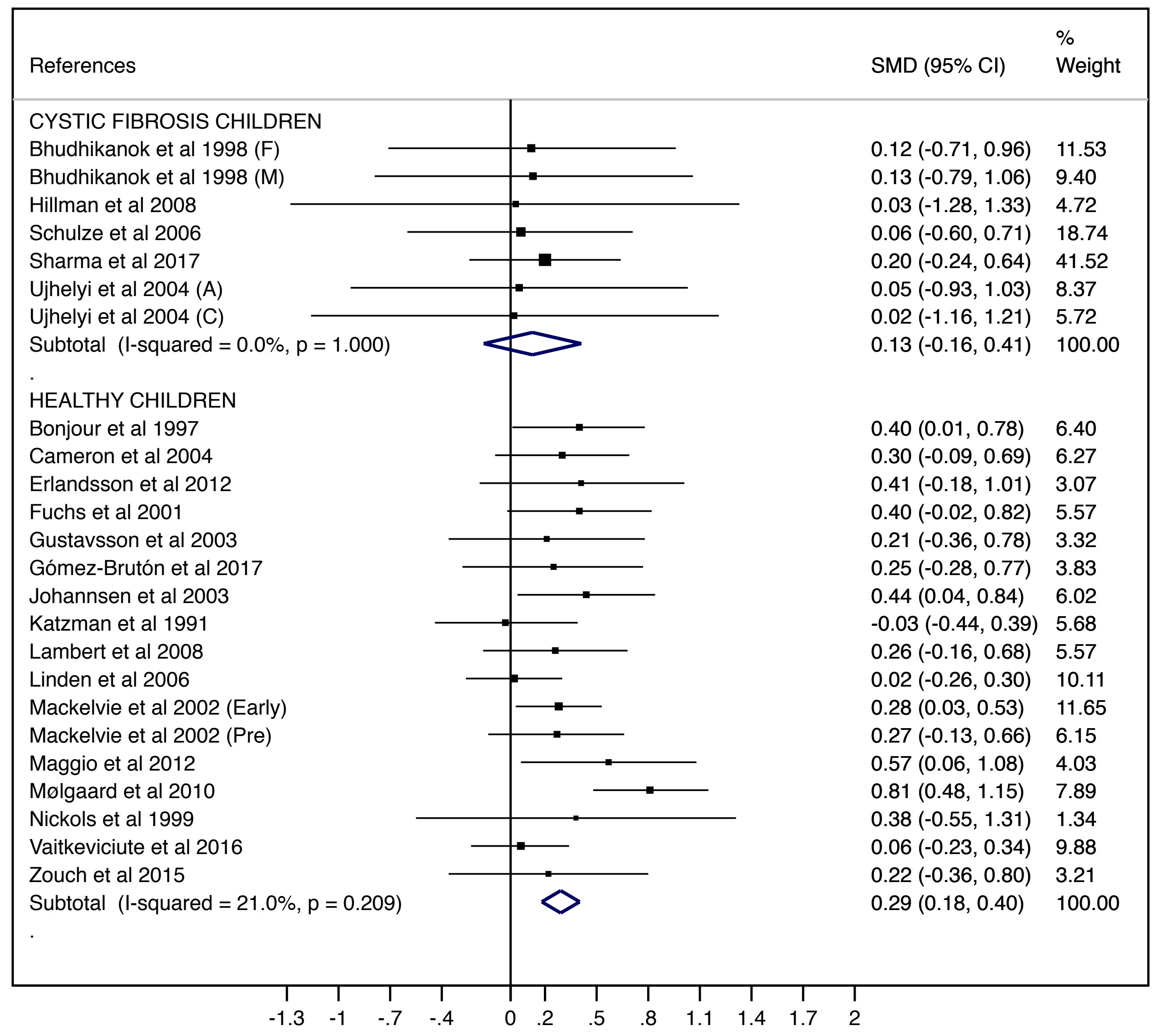




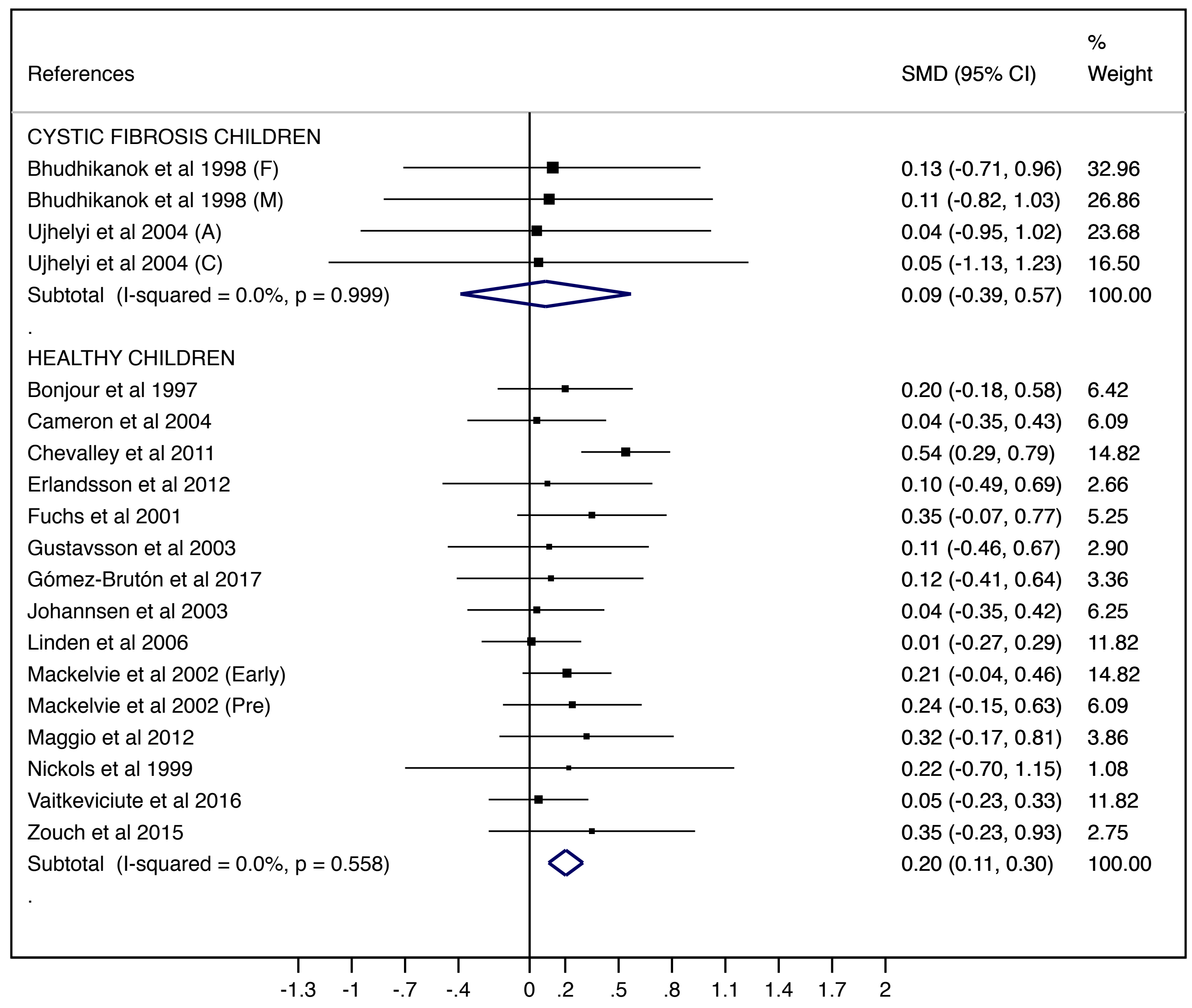

